\title{
Variability and trends of the surface solar spectral ultraviolet irradiance in Italy: a possible influence of lower and upper stratospheric ozone trends
}

5 Sferlazzo $^{4}$

\author{
Ilias Fountoulakis ${ }^{1, a}$, Henri Diémoz ${ }^{1}$, Anna Maria Siani ${ }^{2}$, Alcide di Sarra ${ }^{3}$, Daniela Meloni ${ }^{3}$, Damiano M.
}

${ }^{1}$ Aosta Valley Regional Environmental Protection Agency (ARPA), 11020 Saint-Christophe, Italy

${ }^{2}$ Physics Department, Sapienza Università di Roma, 00185 Rome, Italy

${ }^{3}$ ENEA, Laboratory for Earth Observations and Analyses, 00123, S. Maria di Galeria, Rome, Italy

${ }^{4}$ ENEA, Laboratory for Earth Observations and Analyses, 92010, Lampedusa, Italy

10 aNow at: Institute for Astronomy, Astrophysics, Space Applications and Remote Sensing, National Observatory of Athens (IAASARS/NOA), 15236 Athens, Greece

Correspondence to: Henri Diémoz (h.diemoz@arpa.vda.it)

Abstract. In this study the short- and long-term variability of the surface spectral solar ultraviolet (UV) irradiance are investigated over Italy using high quality ground based measurements from three sites located at quite different environmental conditions, and covering the full latitudinal extent of the Italian territory: Aosta (45.7 ${ }^{\circ} \mathrm{N}, 7.4^{\circ} \mathrm{E}, 570 \mathrm{~m}$ a.s.1.), Rome (41.9 ${ }^{\circ}$ $\mathrm{N}, 12.5^{\circ} \mathrm{E}, 75 \mathrm{~m}$ a.s.1.), and Lampedusa $\left(35.5^{\circ} \mathrm{N}, 12.6^{\circ} \mathrm{E}, 50 \mathrm{~m}\right.$ a.s.1.). The variability of the irradiances at $307.5 \mathrm{~nm}, 324 \mathrm{~nm}$, and of the ratio between the $307.5 \mathrm{~nm}$ and the $324 \mathrm{~nm}$ irradiances were investigated with respect to the corresponding variability in total ozone and the geopotential height at $250 \mathrm{hPa}(\mathrm{GPH})$. The study was performed for two periods: 2006 - 2020 for all stations, and 1996-2020 only for Rome. A statistically significant correlation between the GPH and total ozone monthly

20 anomalies was found for all stations and all seasons of the year. A corresponding statistically significant correlation was also found in most cases between the GPH and the $307.5 \mathrm{~nm}$ irradiance monthly anomalies. The correlation between GPH anomalies at different sites was statistically significant, possibly explaining the strong and significant correlation between the total ozone monthly anomalies at the three sites. A statistically significant decrease of total ozone, of $\sim 0.1 \% /$ year was found for Rome for the period 1996 - 2020, which however did not induce increasing trends in irradiance at $307.5 \mathrm{~nm}$ (neither increasing trends in the ratio between the $307.5 \mathrm{~nm}$ and the $324 \mathrm{~nm}$ irradiances) at $\mathrm{SZA}=67^{\circ}$. Further analyses revealed positive trends in the ratio and the $307.5 \mathrm{~nm}$ irradiance at smaller solar zenith angles (SZA), which can be attributed to the fact that total ozone decrease is driven by a decrease in the lower stratosphere while upper stratospheric ozone increases, and the effect of changes of upper stratospheric ozone becoming disproportionately larger for increasing SZA. It was also showed that long-term changes in total ozone follow changes in GPH, which is an additional indication that negative trends in total ozone

30 are mainly driven by changes in lower stratospheric ozone. An anti-correlation between the GPH long-term changes and total ozone was also evident for all stations in 2006 - 2020. Positive trends in UV irradiance for this latter period which were possibly driven by changes in clouds and/or aerosols were found for Rome and Aosta. This study clearly points out the 
significance of dynamical processes which take place in the troposphere for the variability of total ozone and surface solar UV irradiance.

\section{Introduction}

The amount of solar ultraviolet radiation (UVR) reaching the Earth's surface is an important environmental, ecological and atmospheric parameter to be measured and studied. The relationship between UVR and biological effects has been well established. Exposure to UVR is vital for many living organisms, including humans, however, overexposure may produce detrimental effects in humans, animal and plants (Paul and Gwynn-Jones, 2003; Caldwell et al., 1998; Bornman et al., 2019;

40 Calkins and Thordardottir, 1980; Williamson et al., 2019; Häder et al., 1998). Photons with wavelengths below $290 \mathrm{~nm}$ are absorbed in the higher atmosphere, mainly by molecular oxygen $\left(\mathrm{O}_{2}\right)$ and ozone $\left(\mathrm{O}_{3}\right)$ and practically do not reach the Earth's surface. Most of the ultraviolet-B (UVB) irradiance $(280-315 \mathrm{~nm}$ ) is also absorbed by ozone in the stratosphere (Bais et al., 1993; Griggs, 1968; Inn \& Tanaka, 1953). Absorption by stratospheric ozone dominates on scattering by molecules and aerosols in the UV-B spectral range, while scattering plays a relatively larger role than ozone absorption in the UV-A.

45 In the 1980s and 1990s, the increase of anthropogenic emissions of ozone depleting substances (ODS) enhanced the chemical destruction of ozone in the stratosphere mainly over Arctic and Antarctica, leading to reduced stratospheric ozone even at midlatitudes of the Southern and the Northern hemispheres (Solomon et al., 1986; McConnell et al., 1992), and subsequently to higher levels of UVB radiation at the Earth's surface (Madronich et al., 1998; Kerr and McElroy, 1993; Zerefos et al., 1995). Emissions of ODS were regulated after the adoption of the Montreal Protocol in 1987 and subsequent amendments and adjustments, and since the mid-1990s the reduction of stratospheric ozone has decelerated. The first signs of recovery are now evident over higher latitudes (Weber et al., 2018; Solomon et al., 2016). Recent studies show that recovering ozone over Antarctica resulted on decreasing UVB radiation (Bernhard and Stierle, 2020). Over the Arctic, many studies report negative, but in most cases not significant, trends of UVB radiation in spring (Eleftheratos et al., 2015; Lakkala et al., 2017; Svendby et al., 2018). Due to the successful implementation of the Montreal protocol the world avoided extremely high levels of solar

55 UVB radiation which would have been detrimental for the viability of ecosystems, as well as for human health (Morgenstern et al., 2008; Newman and McKenzie, 2011; McKenzie et al., 2019).

However, the future evolution of total ozone levels, and subsequently of UVB radiation is still uncertain. Although decreasing ODS since mid-1990s led to increasing ozone in the upper stratosphere since mid-1990s (Steinbrecht et al., 2017; Sofieva et al., 2017), lower stratospheric ozone in the Northern mid-latitudes has been continuously decreasing, offsetting the increase

60 occurring in the upper stratosphere (Wargan et al., 2018; Ball et al., 2018). Changes in lower stratospheric ozone appear to have a strong spatial and seasonal variability, and the processes that drive them are not clear yet (Szeląg et al., 2020). Furthermore, dynamical phenomena occasionally (once every few years) favor extensive destruction of Arctic stratospheric ozone in early spring (Dameris et al., 2021; Manney et al., 2011; Pommereau et al., 2018; Varotsos et al., 2012; Wohltmann et al., 2020), leading to extremely low ozone over Northern hemisphere high and mid-latitudes (due to the transport of poor- 
ozone air masses from the poles towards mid-latitudes), and subsequently to very high levels of solar UVB radiation at the Earth's surface (Bernhard et al., 2020; Petkov et al., 2014). In addition, low ozone episodes (Siani et al., 2002) not related to ozone over the poles can be experienced. These episodes are characterized by significant ozone decreases over limited geographical regions and are associated with synoptic weather systems. An increasing frequency of the occurrence of such phenomena in the future could strongly affect the ozone levels in the atmosphere, and subsequently the terrestrial levels of UVB. As discussed in several studies (e.g., Dobson et al., 1946; Reed, 1950; Hoinka et al., 1996; Varotsos et al., 2004; Angell and Korshover, 1964; Steinbrecht et al., 1998; Vaughan and Price, 1991), changes in tropopause altitude are linked to inverse changes in the amount of total ozone. Thus, increasing altitude of the tropopause due to climate change related warming of the troposphere would induce negative trends in lower stratospheric ozone, and subsequently positive trends in UVB.

Over many mid-latitude stations of the Northern hemisphere, changes in aerosols and clouds - and not ozone - have been

75 found to be the main drivers of the long-term changes of the UVB and the UVA irradiance (Chubarova et al., 2020; De Bock et al., 2014; Fitzka et al., 2012; Fountoulakis et al., 2016; Fountoulakis et al., 2018; Hooke et al., 2017; Zhang et al., 2019). Aerosols and clouds also play a significant role in the short-term variability of UVA and UVB irradiance (e.g., Mateos et al., 2015; Kazadzis et al., 2009; di Sarra et al., 2008; Mateos et al., 2011). Two different studies (Fragkos et al., 2016), and Raptis et al., 2021) report moderate or even low erythemal irradiance (McKinlay and Diffey, 1987) during extremely low ozone

80 events, because of remarkably high aerosol load. The trends reported in different studies for the period between mid-1990s to present vary significantly even within a few hundreds of kilometres. Fountoulakis et al., (2020b) reported an average increase of $5 \%$ per decade in the $307.5 \mathrm{~nm}$ irradiance for Uccle, Belgium in 1996 - 2017, and for the same period an average decrease of $7 \%$ per decade for Reading, UK, which is less than $400 \mathrm{~km}$ from Uccle. Other, independent studies report similar results for the two stations. Hooke et al. (2017) reported an $8 \%$ decrease in erythemal doses for Chilton, UK (located a few kilometers

85 from Reading) in 1991 - 2015, while De Bock et al., (2014) and Pandey et al., (2016) reported positive trends in Uccle (in 1991 - 2013 and 1995 - 2014 respectively).

The UV irradiance spatial variability in Italy is very large, mainly due to the country's long latitudinal extent and complex topography (Meloni et al., 2000). Thus, atmospheric parameters may affect UVB and UVA irradiance in a different way at different locations (e.g., Fountoulakis et al., 2020). Recent studies have shown that atmospheric parameters which affect 90 significantly solar UV radiation, such as clouds (Manara et al., 2016; Manara et al., 2015; Mateos et al., 2011; Pfeifroth et al., 2018) and aerosol (Orza and Perrone, 2015; Rizza et al., 2019; Di Ianni et al., 2018; Putaud et al., 2014; Masiol et al., 2017; di Sarra et al., 2008) have changed in Italy in the last decades, either on a regional or on a country scale. Although in Italy long-term continuous solar spectral UV (Diémoz et al., 2011) and total ozone measurements (Siani et al., 2018) are available from different stations across the country, they have never been used to study the long-term changes of UV irradiance at the 95 surface, and how they are affected by changes in total ozone. In this study, the long-term datasets of high-quality spectral UV and total ozone measurements of three Italian sites (Aosta, Rome, and Lampedusa), located at quite different latitudes and environmental conditions were used in order to study the changes of solar UV irradiance, and the extent at which they are 
driven by changes in total ozone. Furthermore, there was an effort to investigate whether, and to what extent changes in synoptical atmospheric circulation affect the surface solar UV irradiance short- (e.g., yearly) and long-term variability.

The paper is structured as follows. In Sect. 2 the data and methods used for the study are described. In Sect. 3.1 the possible links between the short-term variability of UV irradiance and atmospheric dynamics are studied. In Sect. 3.2 the trends of spectral UV irradiance and total ozone for the three stations are analyzed and discussed with respect to their main drivers. Finally, in Sect. 4 the main findings and the conclusions of the study are summarized.

\section{Data and methodology}

Long series of high-quality spectral UV measurements are available from three Italian stations, providing a complete latitudinal coverage of Italy (Fig. 1). The Aosta monitoring station at the facilities of Regional Environmental Protection Agency of the Aosta Valley (ARPA Valle d'Aosta) $\left(45.7^{\circ} \mathrm{N}, 7.4^{\circ} \mathrm{E}, 570 \mathrm{~m}\right.$ a.s.1.) is a semi-rural site (at Aosta-Saint-Christophe), in the North-Western Alps. The site of the Physics Department of Sapienza University of Rome ( $41.9^{\circ} \mathrm{N}, 12.5^{\circ} \mathrm{E}, 75 \mathrm{~m}$ a.s.1.) is an urban site at a distance of about 25 kilometres from the Tyrrhenian Sea. The Lampedusa Station for Climate Observations of the Italian Agency for the New Technologies, Energy and Sustainable Economic Development (ENEA), located on the island of Lampedusa $\left(35.5^{\circ} \mathrm{N}, 12.6^{\circ} \mathrm{E}, 50 \mathrm{~m}\right.$ a.s.l.) is a background remote (island) site.

At Rome the total column of ozone has been measured by a single monochromator Brewer (MkIV type) with serial number 67 (Brewer\#067) since 1992 (Siani et al., 2018). Measurements of the spectral irradiance have been performed by the same instrument since 1996, at wavelengths $290-325 \mathrm{~nm}$ with a step of $0.5 \mathrm{~nm}$ and a resolution of $\sim 0.6 \mathrm{~nm}$ (Casale et al., 2000).

115 The world travelling reference standard Brewer (Brewer\#017) (maintained by the International Ozone Services Inc.; https://www.io3.ca/index.php) transfers the calibration from the reference triad maintained by Environment and Climate Change Canada (Fioletov et al., 2005; Zhao et al., 2020) to field instruments. Hereafter the travelling reference standard Brewer is referred as IOS standard. Intercomparisons between Brewer\#067 and the IOS standard are performed on an annual or biennial basis ensuring the optimal quality of total ozone measurements. As discussed in the following, regular intercomparisons between the IOS standard and the Brewer spectrophotometers at Lampedusa and Aosta ensure the consistency between the total ozone datasets recorded at the three stations. Inter-comparisons with the UV reference standard Quality assurance of spectral ultraviolet measurements in Europe through the development of a transportable unit (QASUME; Hülsen et al., 2016; Gröbner and Sperfeld, 2005) (hereafter referred as QASUME) in 2003 - 2008 and with IOS standard thereafter, performed every 2-3 years, ensure the high quality of the spectral UV measurements. The consistency between the UV spectra measured by QASUME and the IOS standard is ensured by the common participation of both instruments in the intercomparison campaigns on an annual or biennial basis (e.g., Redondas et al., 2018; Redondas \& Rodriguez-Franco, 2015). For the present study measurements of total ozone and spectral UV irradiance for 1996-2020 have been used. Note that spectral UV measurements for the first six months of 2018 were not used for Rome because operational problems induced increased uncertainty in the measurements. 
130 At Lampedusa measurements of total ozone and spectral UV irradiance have been performed since 1997 by a double monochromator Brewer (MkIII type) with serial number 123 (Brewer\#123) (di Sarra et al., 2002). Solar spectra are measured in the range $286-363 \mathrm{~nm}$ with a step of $0.5 \mathrm{~nm}$ and a resolution of $\sim 0.55 \mathrm{~nm}$. Calibrations of spectral UV measurements are performed 4-5 times per year with a field calibrator which uses 1000 W FEL lamps traceable to NIST (di Sarra et al., 2008). Regular inter-comparisons (every $2-4$ years since 1998) with the IOS standard ensure the good quality of total ozone measurements. The Lampedusa spectral UV dataset has been recently subjected to QA/QC and homogenized for the period 2003 - 2020. For the present study measurements of the total ozone and spectral UV irradiance have been used for the period for which high quality measurements are available for all three sites (i.e., 2006 - 2020).

At Aosta, spectral UV-visible measurements are performed by a double monochromator Bentham DTMc300 with serial number 5541 (Bentham5541) in the range $290-500 \mathrm{~nm}$ with a step of $0.25 \mathrm{~nm}$ and a resolution of $\sim 0.5 \mathrm{~nm}$. Spectral UV

140 measurements began in 2004. Since 2006 inter-comparison with QASUME is performed on an annual or biennial basis ensuring the high quality of the measurements. Recently the spectral UV dataset of Aosta was re-evaluated and homogenized for the period 2006 - 2020 (Fountoulakis et al., 2020a). Measurements of the total ozone are available since 2007 by a single monochromator Brewer (MkIV type) with serial number 66 (Brewer\#066). The quality of total ozone measurements is ensured by inter-comparisons with the IOS standard, which have been performed since 2007 on a biennial basis. Total ozone and

145 spectral UV measurements for Aosta have been analysed for 2007 - 2020 and 2006-2020, respectively.

The good quality of the total ozone and spectral UV measurements is further ensured by performing stability checks and applying a number of quality control/quality assurance procedures on a regular (daily, weekly, or monthly basis) at each of the three sites described above (Fountoulakis et al., 2020b; Ialongo et al., 2010). The accuracy of total ozone columns retrieved by measuring irradiances of direct sunlight radiation (DS mode) (Kerr, 2010) by well-maintained and calibrated Brewer

150 spectrophotometers, such as those used in the present study, is of the order of 1\% (Vanicek, 2006). The consistency between measurements from different instruments (if they are well maintained and calibrated) is also 1\% (Redondas et al., 2018). The standard uncertainty for spectral UV measurements at wavelengths longer than $305 \mathrm{~nm}$ from well maintained and calibrated Brewer spectrophotometers is of the order of 5\% (Garane et al., 2006). The agreement between synchronous spectra from well maintained and similarly calibrated spectrophotometers is also of the order of 5\% (standard deviation of the differences) (Bais

155 et al., 2001). For wavelengths longer than $305 \mathrm{~nm}$ and SZAs below $75^{\circ}$ the standard uncertainty in the spectral UV measurements of Bentham5541 is smaller than 2.5\%. A detailed description of the uncertainties of the spectral UV measurements performed in Aosta can be found in Fountoulakis et al., (2020a).

Spectral measurements at the wavelengths $307.5 \mathrm{~nm}$ (306.5 - $308.5 \mathrm{~nm}$ average) and $324 \mathrm{~nm}$ ( 323 - $325 \mathrm{~nm}$ average) have been analysed for all three sites. Irradiance at $307.5 \mathrm{~nm}$ is strongly affected by total ozone, while the irradiance at $324 \mathrm{~nm}$ is

160 weakly affected by ozone. Although ozone has a stronger effect on wavelengths shorter than $307.5 \mathrm{~nm}$, the particular wavelength was chosen because it is less affected by noise and spectral straylight (relative to shorter wavelengths). For each spectrum, the ratio between the irradiance at the two wavelengths $(307.5 \mathrm{~nm}$ and $324 \mathrm{~nm}$ ) was also calculated and will be herein referred as $307.5 / 324 \mathrm{~nm}$ ratio. Long-term changes of the ratio should be strongly correlated with changes in total ozone. 
For each day, all spectra measured within $+/-2^{\circ}$ around the solar zenith angles (SZA) of $67^{\circ}$ and $45^{\circ}$ were interpolated to the

central SZAs using the empirical relationship proposed by Fountoulakis et al. (2016), and then averaged to calculate the irradiance. The SZA of $67^{\circ}$ is reached throughout the whole year at all three sites, while the SZA of $45^{\circ}$ is reached in the period April - September. Monthly averages of the irradiances and the ratio were calculated for months for which measurements were available for at least 15 days. Daily averages of the total ozone have been used for the calculation of monthly averages, again when measurements for at least 15 days were available. For all three stations, analyses were performed for the period September 2006 - August 2020 (14 years), i.e., the longest period of overlapping measurements. For Rome, analyses were additionally performed for the period September 1996 - August 2020 (24 years). In all cases, monthly climatological averages of each quantity were calculated for the whole available period (2006 - 2020 or 1996 - 2020). Monthly anomalies were calculated by subtracting the monthly climatological averages from the monthly average values. Calculation of trends was performed by applying a least square linear fit to the monthly anomalies and statistical significance was in all cases estimated by applying the Mann-Kendal test.

In addition to the ground-based measurements, re-analysis products from Modern-Era Retrospective analysis for Research and Applications version 2 (MERRA-2) have been used, mainly for the investigation of changes in atmospheric conditions, and ozone at different atmospheric levels. All MERRA-2 products used in the present study were provided in a grid resolution of $0.5^{\circ} \mathrm{x} 0.625^{\circ}$ (latitude $\mathrm{x}$ longitude) and have been downloaded from the Giovanni platform maintained by National Aeronautics and Space Administration (NASA) (https://giovanni.gsfc.nasa.gov/giovanni/). Monthly average total ozone (GMAO, 2015a) for $1996-2020$ and Geopotential Heights (GPH) at $250 \mathrm{hPa}$ and $850 \mathrm{hPa}$ (GMAO, 2015b) have been downloaded and analysed for southern Europe. The Geopotential Height (GPH) was also linearly interpolated to the co-ordinates of Aosta, Rome and Lampedusa in order to study its variability over these sites. Monthly average ozone mixing ratio (GMAO, 2015b) from MERRA-2, at different pressure levels between 150 and $3 \mathrm{hPa}$ for 1996 - 2020 has been interpolated to the coordinates of the station of Rome. The version 7 Aqua/AIRS L3 Monthly Standard Physical Retrieval (AIRS-only) tropopause height product with $1^{\circ} \times 1^{\circ}$ resolution (AIRS3STM) (AIRS project, 2019) was also interpolated to the coordinates of the three stations for the period 2006 - 2020. The AIRS3STM was also downloaded from the same platform. As shown later, positive/negative anomalies in GPH at $250 \mathrm{hPa}$ generally coincide with positive/negative anomalies of the tropopause altitude and positive/negative anomalies in GPH at $850 \mathrm{hPa}$. According to the studies of Varotsos et al., (2004) and Steinbrecht et al., (1998), positive trends in the height of the tropopause explain $25-30 \%$ of the reduction of total ozone over Athens in 1984 2002, and Hohenpeissenberg in 1967 - 1997 respectively.

\section{Short- and long-term variability of UV irradiance}

\subsection{Short-term variability of UV irradiance and the role of changes in GPH}

In this section we investigate whether there is a correlation between the monthly anomalies of the GPH at $250 \mathrm{hPa}$ (hereafter named as GPH unless something different is specified) and the corresponding anomalies of UV irradiance (at $307.5 \mathrm{~nm}, 324$ 
$\mathrm{nm}$ ) and the $307.5 / 324 \mathrm{~nm}$ ratio. Here, and in the following sections, the Pearson (i.e., linear) correlation coefficients are reported. For all cases that a strong correlation was found, it was optimally described by a linear fit. The investigation was performed for all three stations for the period 2006 - 2020. For Rome, the analyses were also performed for the period 1996 2020.

200 Fig. 2 shows the sequence of the correlation analysis among the sites for the different atmospheric parameters. As shown in Fig. 2, the GPH at Aosta and Rome varies in a similar way despite the distance between them and the fact that the two sites are at quite different environments. The correlation coefficient for GPH at the two sites (panel a) is $\sim 0.9$ and indicates that to a wide extent the two sites are affected by the same synoptical systems. This strong correlation is also found for the anomalies of total ozone (panel $\mathrm{m}$ ) and subsequently for the anomalies of the $307.5 \mathrm{~nm}$ irradiance (panel d) and the $307.5 / 324 \mathrm{~nm}$ ratio (panel $\mathrm{j}$ ). The correlation for the $324 \mathrm{~nm}$ irradiance (panel g) is statistically significant but weak ( 0.26). The corresponding correlation between the same variables (with the exception of the $324 \mathrm{~nm}$ irradiance) at Rome and Lampedusa was again significant but weaker than for Rome and Aosta, which however was expected since the latitudinal distance between Rome and Lampedusa $\left(6.4^{\circ}\right)$ is longer than the distance between Rome and Aosta $\left(3.8^{\circ}\right)$. Part of the differences could be also due to the fact that dust outbreaks play a more significant role on the variability of surface UVR over Lampedusa than in Rome and Aosta (e.g., Meloni et al., 2008). A weak but statistically significant correlation between GPH ( 0.5) and total ozone ( $\sim 0.4)$ in Aosta and Lampedusa was found. However, in this latter case the correlation found for total ozone and GPH is not reflected in the levels of UV irradiance. Further analyses showed that for GPH and total ozone the correlation between different sites was generally stronger in winter and weaker in summer. Even for summer, however, the correlation between the aforementioned parameters for the pairs Aosta - Rome and Rome - Lampedusa is statistically significant (in the case of total

215 ozone the correlation is also significant for the pair Lampedusa - Aosta). What is interesting is that the strongest correlation for the $307.5 \mathrm{~nm}$ irradiance and the $307.5 / 324 \mathrm{~nm}$ ratio for all sites was found for summer, which shows that the levels of the $307.5 \mathrm{~nm}$ irradiance over all three sites vary in a similar way, mainly because total ozone also varies in a very similar way. In Table 1 the correlation coefficients between GPH and the UV irradiance at $307.5 \mathrm{~nm}$ and $324 \mathrm{~nm}$ (for SZAs $67^{\circ}$ and $45^{\circ}$ ), $\mathrm{GPH}$ and the $307.5 / 324 \mathrm{~nm}$ ratio (for $\mathrm{SZA}=67^{\circ}$ and $\mathrm{SZA}=45^{\circ}$ ), and $\mathrm{GPH}$ and total ozone are presented. The monthly anomalies for each of the four seasons of the year (December, January, February for winter, March, April, May for spring, June, July, August for summer, and September, October, November for autumn) were used for the calculation of the correlation coefficients. Numbers in bold denote statistical significance (Mann - Kendall method was used to determine statistical significance) at the $95 \%$ confidence level (hereafter the statistical significance at the $95 \%$ confidence level is referred as statistical significance).

225 Variations in the $\mathrm{GPH}$ at $250 \mathrm{hPa}$ are strongly correlated with variations in the tropopause altitude, as well as with variations in the GPH at $850 \mathrm{hPa}$ (i.e., near the surface) (see Appendix I). Thus, the results presented in Table 1 partially confirm the findings of previous studies reporting correlation between tropospheric dynamics variability and total ozone, since a strong and statistically significant anti-correlation between total ozone and GPH was also found for all Italian stations and all seasons. The correlation is slightly lower in summer relative to other seasons (especially in Aosta). A possible explanation is that the 
relatively stable synoptical conditions in summer lead to much smaller variability in GPH relative to other seasons of the year, which in turn possibly has a weaker effect on total ozone. As discussed in the following sections, changes in GPH also play a significant role in the long-term changes of total ozone over Italy.

The anti-correlation between total ozone and GPH was associated with, in most cases, a statistically significant correlation between GPH and the 307.5/324 nm ratio. The correlation between the GPH and the ratio was generally stronger for Aosta than for Lampedusa and Rome. This is possibly because variations of the GPH are linked to larger variations of the total ozone at higher latitudes, given that the amount and the variability of total ozone increase with increasing latitude. The correlation between GPH and the $307.5 \mathrm{~nm}$ irradiance was also statistically significant in most cases. In some cases (e.g., Aosta in autumn) the correlation between GPH and the $307.5 / 324 \mathrm{~nm}$ ratio is much stronger than the correlation between GPH and the $307.5 \mathrm{~nm}$ irradiance. As already discussed, the variability of the ratio was mainly determined by the variability of total ozone, while the

$240307.5 \mathrm{~nm}$ irradiance was also affected by the variations of factors such as clouds and most types of aerosols which have a relatively flat spectral effect in the range $307.5-324 \mathrm{~nm}$.

It is interesting to note that in addition to the significant correlation between GPH and the $307.5 \mathrm{~nm}$ irradiance, strong and statistically significant correlation was found between GPH and the $324 \mathrm{~nm}$ irradiance for Rome. For $45^{\circ}$ the correlation was significant for spring and summer. For $67^{\circ}$ the correlation was significant for all seasons for $2006-2020$, and for all seasons except summer for 1996 - 2020. The correlation coefficients were generally larger for 2006 - 2020 relative to $1996-2020$. Statistically significant correlation between the $324 \mathrm{~nm}$ irradiance and the GPH has been found for Lampedusa in winter and for Aosta in autumn. The strong link between GPH and the $324 \mathrm{~nm}$ irradiance may be related to changes in aerosols and clouds, associated with changes in synoptical meteorological conditions. Aerosol and clouds, in their turn, affect the levels of both UVB and UVA irradiance levels. Changes in GPH at $250 \mathrm{hPa}$ were strongly anti-correlated to changes in atmospheric pressure near the surface (see Fig. S.1 in the supplement), which were strongly linked to changes in cloudiness and wind patterns (both of which also affect aerosol load).

The results presented in Table 1 show clearly that total ozone and surface UVR are affected not only by dynamical processes that take place in the stratosphere (e.g., Monge-Sanz et al., 2003; Neu et al., 2014; Weber et al., 2011), but they can be also affected significantly by processes that take place in the troposphere.

\subsection{Long-term variability of spectral UV irradiance and total ozone}

\subsubsection{Long-term variability in the period $2006-2020$}

In this section the results of the analysis of the long-term changes for the same quantities as those discussed in Sect. 3 are presented and discussed for the period September 2006 - August 2020, during which, measurements were available for all three stations: Aosta, Rome, and Lampedusa. The estimated trends of the irradiances at $307.5 \mathrm{~nm}$ and $324 \mathrm{~nm}$, and the $307.5 / 324 \mathrm{~nm}$ ratio at $\mathrm{SZA}=67^{\circ}$ are presented in Fig. 3, while the corresponding trends for $\mathrm{SZA}=45^{\circ}$ are presented in Fig. 
4. The trends were also calculated separately and are presented for each month of the year. The estimated trends for total ozone (from ground-based measurements) and GPH are presented in Fig. 5.

Statistically significant change (of $0.15 \% / y e a r$ ) was found only for the $307.5 \mathrm{~nm}$ irradiance in July at Aosta (Fig. 3a). For the same month neither the $307.5 / 324 \mathrm{~nm}$ ratio nor the $324 \mathrm{~nm}$ irradiance changed significantly, although they increased with an average rate of $\sim 0.7 \%$ /year. It is possible here that the natural variability masks the presence of trends. The overall increase of the 307.5 irradiance for $2006-2020$ is $\sim 2 \%$, and although it is statistically significant, it is less than the standard uncertainty in the measurements. Thus, this result should be treated with caution. In November an increase in total ozone over Aosta, of $0.7 \% / y e a r$ was found, which again coincides with a decrease of the GPH, which however is not statistically significant. The $307.5 \mathrm{~nm}$ irradiance and the $307.5 / 324 \mathrm{~nm}$ ratio also decreased in the same month, but their decrease was again not statistically significant.

At the SZA of $45^{\circ}$ the $324 \mathrm{~nm}$ the irradiance in August increased over Aosta by $0.6 \% / y e a r$. An increase of similar magnitude, but not statistically significant, was found for the $307.5 \mathrm{~nm}$ irradiance, while the $307.5 / 324 \mathrm{~nm}$ ratio remained relatively stable. In the same month total ozone did not change, which justifies the absence of significant trend in the ratio. However, the GPH increased significantly by $0.07 \%$ year, which may be related with changes in cloudiness and/or aerosols (e.g., Manara et al., 2016)). Since changes in aerosols and cloudiness have a stronger effect on the direct component of the solar irradiance (scattered irradiance in the UV is mainly redistributed rather than backscattered by aerosols and clouds) the changes in UV are more pronounced for $45^{\circ}$ relative to $67^{\circ}$ because direct component has a more significant contribution at smaller SZA.

At Lampedusa neither the UV irradiance nor the ratio changed significantly for both SZAs $\left(45^{\circ}\right.$ and $\left.67^{\circ}\right)$. Total ozone also did not change at Lampedusa for none of the twelve months. The statistically significant increase in GPH in September at 280 Lampedusa does not coincide with any statistically significant change of ozone or UV irradiance.

The UV irradiance in April at Rome did not change significantly at SZA $=67^{\circ}$, but increased significantly for both, $307.5 \mathrm{~nm}$ and $324 \mathrm{~nm}$, by $\sim 1 \% /$ year at $\mathrm{SZA}=45^{\circ}$. The $307.5 / 324 \mathrm{~nm}$ ratio also increased, but the increase was not statistically significant. In the same month total ozone decreased and GPH increased, but again, neither of these latter changes was significant. These results show that changes in total ozone are not the dominant driver of changes in UV irradiance in 2006 - 2020, and that other factors such as aerosols and clouds play a more important role.

\subsubsection{Long-term variability in the period $1996-2020$}

In Fig. 6 the monthly anomalies of the $307.5 \mathrm{~nm}$ irradiance, the $324 \mathrm{~nm}$ irradiance, the $307.5 / 324 \mathrm{~nm}$ ratio, and the total ozone are presented for Rome for the period September 1996 - August 2020 at the SZA of 67.5 . Moving averages and the linear trends for the four quantities are also presented in the same figure. The calculated trends and the corresponding $\mathrm{p}$-values are presented in Table 2. A negative, statistically significant trend of $-0.1 \% /$ year was found for total ozone, corresponding to a decrease of $\sim 2.4 \%$ during the 24 -year period. Although total ozone decreases, neither the $307.5 \mathrm{~nm}$ irradiance, nor the $307.5 / 324 \mathrm{~nm}$ ratio increase. 
The trends for each month were calculated for the 24-year period and are presented in Fig. 7. Analyses were performed for both SZAs, $67.5^{\circ}$ and $45^{\circ}$. In addition to the trends of spectral irradiance, the results for the $307.5 / 324 \mathrm{~nm}$ ratio are presented. The long-term changes of GPH and total ozone (measured by Brewer\#067) were also investigated and are presented in Fig. 8. For the SZA of $67^{\circ}$ the irradiance at both wavelengths did not change significantly for any of the 12 months of the year. The ratio decreased significantly only in March, on average by $-0.2 \%$ year. In general, significant changes in total ozone did not correspond to significant changes in the $307.5 / 324 \mathrm{~nm}$ ratio as expected. Total ozone decreased significantly in April (with an average rate of $-0.4 \%$ year), September (with an average rate of $-0.2 \% /$ year), and October (with an average rate of $0.15 \% / y e a r$ ). However, for the SZA of $45^{\circ}$ the $307.5 / 324 \mathrm{~nm}$ ratio increased significantly in April (by $\sim 0.35 \% / y e a r$ ), August and September (for both months by $0.2 \%$ year), inversely following the negative total ozone trends. Unfortunately, measurements for $\mathrm{SZA}=45^{\circ}$ are available only for the period April - September at Rome due to the geographical position of the station.

It can be also perceived from Fig. 8 that trends in total ozone inversely follow the trends of GPH, which is a strong indication that trends in total ozone are related with dynamical changes in troposphere and the lower stratosphere, which in turn shows that at least part of the trends is due to reduction of ozone at the lower stratosphere. Many recent studies show that at the midlatitudes of the northern hemisphere ozone increases at the higher stratosphere and decreases at the lower stratosphere (Sofieva et al., 2017; Eleftheratos et al., 2020; Ball et al., 2019; Staehelin et al., 2001). Thus, an explanation of the results presented in Figures 6, 7 and 8 could be that the negative trends in lower stratospheric ozone dominate over positive trends in higher stratospheric ozone at Rome, resulting to an overall decrease in total ozone. As the SZA increases the role of ozone at the middle and upper atmosphere becomes more important regarding the attenuation of the UV-B irradiance relative to ozone at the lower stratosphere. Qualitative analysis of the monthly average ozone mixing ratio at different pressure levels between 100 and $3 \mathrm{hPa}$ for the period of study over Rome (see Fig. S.2 in the supplement) confirmed that ozone increases at lower pressure levels and decreases at higher pressure levels, confirming the finding of previous studies. A detailed quantitative analysis is however out of the scope of the present study.

Figure 9 shows the trends of total ozone (from MERRA-2) and GPH in a wider spatial scale for the months of April and September for which statistically significant changes in total ozone were found. These plots suggest that changes over Rome are part of changes taking place over wider spatial scales. Although deriving trends of the total ozone from MERRA-2 is more uncertain than deriving trends from good quality ground-based measurements (Zhao et al., 2021), the graphs in Fig. 9 still show clearly that for the considered months (April and September), negative trends in total ozone coincide with positive trends in the GPH (which denotes shift of the tropopause towards higher altitudes) over wide areas. This was not the case for October for which changes in GPH did not coincide spatially with changes in total ozone. Although it is not safe to draw quantitative conclusions from this analysis, it indicates that dynamical changes in the atmosphere could possibly play a significant role in affecting ozone changes. 


\section{Summary and conclusions}

In the present study the variability of solar UV irradiance at $307.5 \mathrm{~nm}$ and $324 \mathrm{~nm}$, and the $307.5 / 324 \mathrm{~nm}$ ratio was analysed with respect to the variability of total ozone and GPH. Analyses were performed for the sites of Rome, Aosta, and Lampedusa, where long-term and high quality measurements of spectral irradiance and total ozone are available for the period $2006-2020$. For Rome, analyses were also performed for 1996 - 2020.

330 Statistically significant anti-correlation was found between the year-to-year variability of GPH and total ozone for all three sites and all seasons of the year, which confirms the findings of studies reporting that variability in troposphere dynamics is strongly correlated with the variability in total ozone (e.g., Ball et al., 2019; Staehelin et al., 2001). The anti-correlation between total ozone and GPH induced a corresponding correlation between GPH and the $307.5 \mathrm{~nm}$ irradiance, and between GPH and the $307.5 / 324 \mathrm{~nm}$ ratio, which in most cases was significant. Correlation between GPH and the $307.5 \mathrm{~nm}$ irradiance (and GPH and the $307.5 / 324 \mathrm{~nm}$ ratio) was stronger for Aosta relative to Rome and Lampedusa, which can be attributed (at least partially) to the fact that total ozone at higher latitudes generally reaches higher values. Thus, variations in GPH induce larger absolute changes in total ozone and subsequently the UVB irradiance. At Rome, the GPH was also correlated significantly with the 324 $\mathrm{nm}$ irradiance (for anomalies in 2006 - 2020 the correlation coefficients for all seasons were $\sim 0.4$ ), possibly because changes in GPH were also linked to changes in clouds and aerosols.

340 The correlation between the GPH at Rome and Aosta was strong ( 0.9) and showed that the two sites were frequently affected by the same synoptical systems. The strong correlation between GPH at the two sites corresponded to a strong correlation between total ozone ( 0.67), the $307.5 \mathrm{~nm}$ irradiance ( 0.74), and the $307.5 / 324 \mathrm{~nm}$ ratio $(\sim 0.75)$ at the two sites. Statistically significant, but weak, correlation was also found for the $324 \mathrm{~nm}$ irradiance at Rome and Aosta ( 0.26). The correlation between GPH at Rome and Lampedusa was again strong and significant ( 0.75), while the correlation between GPH at Lampedusa and

345 Aosta was also statistically significant but weaker ( 0.48). In both cases the correlation for total ozone was statistically significant, $\sim 0.5$ and $\sim 0.4$ respectively, but the correlation for the irradiance at $307.5 \mathrm{~nm}$ and the $307.5 / 324 \mathrm{~nm}$ ratio was weak, although in some cases it was statistically significant.

The strong correlation between the monthly anomalies of the GPH (and subsequently between the total ozone anomalies) in Aosta, Rome, and Lampedusa was depicted to their long-term trends in 2006 - 2020 which were toward the same direction

350 (i.e, the GPH was increasing/decreasing at all sites) for most months of the year. However, the long-term trends of GPH and total ozone were not statistically significant in most cases. For SZA $=67^{\circ}$ the irradiance at $307.5 \mathrm{~nm}$ and $324 \mathrm{~nm}$ did not change significantly in $2006-2020$ at none of the three sites. However, the UV irradiance at $307.5 \mathrm{~nm}$ and $324 \mathrm{~nm}$ increased significantly by $\sim 0.7 \%$ year, in Rome at $\mathrm{SZA}=45^{\circ}$ possibly due to changes in clouds and/or aerosols. At Aosta increases of similar magnitude were found for the $307.5 \mathrm{~nm}$ and the $324 \mathrm{~nm}$ irradiances (only the latter was statistically significant) at $45^{\circ}$

355 in August, which were possibly mostly driven by changes in clouds and/or aerosols. The increase in UV irradiance in August at Aosta coincided with a statistically significant increase in the GPH, which was not however the case for the changes in UV irradiance in April at Rome. Changes possibly driven by clouds and/or aerosols were found at $\mathrm{SZA}=45^{\circ}$ and not at $\mathrm{SZA}=$ 
$67^{\circ}$, which can be explained by the fact that clouds and aerosols, both have a stronger effect on the direct relative to the diffuse component of the solar irradiance. The direct component becomes less significant as the SZA decreases, leading to less significant trends of the irradiance.

The large, statistically significant increase of total ozone at Aosta in November (during 2006 - 2020), by 0.8\%/year induced a negative trend of $\sim 1 \% /$ year in the $307.5 / 324 \mathrm{~nm}$ ratio at $67^{\circ} \mathrm{SZA}$, which was not however statistically significant. According to di Sarra et al., (2002) a change of $\sim 1 \%$ in total ozone at that SZA should induce a change of $2-3 \%$ in the irradiance at $307.5 \mathrm{~nm}$. The difference between the observed and the expected change in the irradiance at $307.5 \mathrm{~nm}$ can be attributed to the 365 fact that ozone changed differently at different levels in the atmosphere.

Changes in troposphere dynamics in April and September, which took place on a wide spatial scale during 1996 - 2020, led to decreased total ozone over Rome, which in turn resulted to statistically significant increases in the $307.5 / 324 \mathrm{~nm}$ ratio at $45^{\circ}$ SZA. Total ozone also decreased in October, although no statistically significant change of GPH was found, resulting again in a significant increase in the $307.5 / 324 \mathrm{~nm}$ ratio at $45^{\circ} \mathrm{SZA}$. In all above cases the changes in total ozone and the 307.5/324 nm ratio were in good agreement with the RAF (Radiation Amplification Factor) reported by (di Sarra et al., 2002). The $307.5 / 324 \mathrm{~nm}$ ratio at $67^{\circ} \mathrm{SZA}$ decreased significantly in March at the same site and for the same period, although no statistically significant change of total ozone was found. In general, the results for Rome for 1996 - 2020 can be explained by the decreasing ozone in the lower stratosphere and the increasing ozone in the upper stratosphere. The two processes are competitive to each other regarding their effect on UVB irradiance, with a stronger influence on UVB of the lower stratospheric ozone decrease at the small SZA.

Concluding, the present study shows that total ozone over the Northern part of Italy decreased in the last decades mainly because of changes in the dynamics of the troposphere, the effect of which is dominant over the ozone recovery in the upper stratosphere. The overall decrease of total ozone has a stronger effect on the irradiance at $307.5 \mathrm{~nm}$ at smaller SZAs, since the relative contribution of upper stratospheric ozone to the attenuation of UVB irradiance becomes more significant with increasing SZA. Changes in cloudiness and/or aerosols also may alter the levels of UV irradiance at Aosta and Rome. More robust statistical analyses and radiative transfer modelling are necessary in order to quantify the relative contribution of different factors to the short- and long-term changes of the surface solar UV irradiance in Italy, which however is out of the scope of the present study. In any case, this study shows very clearly that changes in the troposphere can play a key role in the formulation of the levels of total ozone and surface UV radiation. Synoptical circulation patterns and changes were found to be linked, not only to changes in total ozone, but also in UVB, and in some cases in UVA, irradiance. Since significant change in the dynamics of the troposphere are projected for the future (e.g., IPCC, 2013), thorough investigation is necessary in order to determine their possible impact on the future levels of surface UV radiation. 


\section{Data availability}

The ground based total ozone and spectral UV measurements used in this study can be made available upon request to the PIs of the stations. All re-analysis and satellite products used in the present study have been downloaded from the Giovanni platform maintained by National Aeronautics and Space Administration (NASA) (https://giovanni.gsfc.nasa.gov/giovanni/).

\section{Author contributions}

IF and HD conceptualized the paper. IF led the paper preparation and performed the data analysis. HD is responsible for the ground-based total ozone and spectral UV measurements in Aosta. AMS is responsible for the ground-based total ozone and spectral UV measurements in Rome. AdS, DM, and DS are responsible for the ground-based total ozone and spectral UV measurements in Lampedusa. All authors contributed to the writing of the paper.

\section{Acknowledgements}

Measurements at Lampeudusa were maintained thanks to support from the Italian Ministry for University and Research through projects NextData and Marine Hazard, and the Italian Space Agency through the PRISCAV project. Observations also contribute to the Aerosol, Clouds and Trace Gases Research Infrastructure. Contributions by Francesco Monteleone and Giandomenico Pace are grate-fully acknowledged. Part of the analyses used in this paper were produced with the Giovanni online data system, developed and maintained by the NASA GES DISC.

\section{References}

AIRS project: Aqua/AIRS L3 Monthly Standard Physical Retrieval (AIRS-only) 1 degree x 1 degree V7.0, Greenbelt, MD,

USA, Goddard Earth Sciences Data and Information Services Center (GES DISC), Accessed: 25/06/2021, https://doi.org/10.5067/UBENJB9D3T2H, 2019.

Angell, J. K. and Korshover, J.: Quasi-biennial variations in temperature, total ozone, and tropopause height, J. Atmos. Sci., 21, 479-492, 1964.

Bais, A. F., Zerefos, C. S., Meleti, C., Ziomas, I. C., and Tourpali, K.: Spectral measurements of solar UVB radiation and its relations to total ozone, SO2, and clouds, J. Geophys. Res. Atmos., 98, 5199-5204, https://doi.org/https://doi.org/10.1029/92JD02904, 1993.

Bais, A. F., Gardiner, B. G., Slaper, H., Blumthaler, M., Bernhard, G., McKenzie, R., Webb, A. R., Seckmeyer, G., Kjeldstad, B., Koskela, T., Kirsch, P. J., Gröbner, J., Kerr, J. B., Kazadzis, S., Leszczynski, K., Wardle, D., Josefsson, W., Brogniez, C., Gillotay, D., Reinen, H., Weihs, P., Svenoe, T., Eriksen, P., Kuik, F., and Redondas, A.: SUSPEN intercomparison of 
https://doi.org/https://doi.org/10.1029/2000JD900561, 2001.

Ball, W. T., Alsing, J., Mortlock, D. J., Staehelin, J., Haigh, J. D., Peter, T., Tummon, F., Stübi, R., Stenke, A., Anderson, J., Bourassa, A., Davis, S. M., Degenstein, D., Frith, S., Froidevaux, L., Roth, C., Sofieva, V., Wang, R., Wild, J., Yu, P., Ziemke, J. R., and Rozanov, E. V: Evidence for a continuous decline in lower stratospheric ozone offsetting ozone layer recovery, 18, 1379-1394, https://doi.org/10.5194/acp-18-1379-2018, 2018.

Ball, W. T., Alsing, J., Staehelin, J., Davis, S. M., Froidevaux, L., and Peter, T.: Stratospheric ozone trends for 1985-2018: sensitivity to recent large variability, 19, 12731-12748, https://doi.org/10.5194/acp-19-12731-2019, 2019.

Bernhard, G. and Stierle, S.: Trends of UV Radiation in Antarctica, https://doi.org/10.3390/atmos11080795, 2020.

Bernhard, G. H., Fioletov, V. E., Grooß, J.-U., Ialongo, I., Johnsen, B., Lakkala, K., Manney, G. L., Müller, R., and Svendby, 425 T.: Record-Breaking Increases in Arctic Solar Ultraviolet Radiation Caused by Exceptionally Large Ozone Depletion in 2020, Geophys. Res. Lett., 47, e2020GL090844, https://doi.org/https://doi.org/10.1029/2020GL090844, 2020.

De Bock, V., De Backer, H., Van Malderen, R., Mangold, A., and Delcloo, A.: Relations between erythemal UV dose, global solar radiation, total ozone column and aerosol optical depth at Uccle, Belgium, 14, 12251-12270, https://doi.org/10.5194/acp14-12251-2014, 2014.

430 Bornman, J. F., Barnes, P. W., Robson, T. M., Robinson, S. A., Jansen, M. A. K., Ballaré, C. L., and Flint, S. D.: Linkages between stratospheric ozone, UV radiation and climate change and their implications for terrestrial ecosystems, Photochem. Photobiol. Sci., 18, 681-716, https://doi.org/10.1039/C8PP90061B, 2019.

Caldwell, M. M., Björn, L. O., Bornman, J. F., Flint, S. D., Kulandaivelu, G., Teramura, A. H., and Tevini, M.: Effects of increased solar ultraviolet radiation on terrestrial ecosystems, J. Photochem. Photobiol. B Biol., 46, 40-52, 435 https://doi.org/https://doi.org/10.1016/S1011-1344(98)00184-5, 1998.

Calkins, J. and Thordardottir, T.: The ecological significance of solar UV radiation on aquatic organisms, Nature, 283, 563566, https://doi.org/10.1038/283563a0, 1980.

Casale, G. R., Meloni, D., Miano, S., Palmieri, S., Siani, A. M., and Cappellani, F.: Solar UV-B irradiance and total ozone in Italy: Fluctuations and trends, J. Geophys. Res. Atmos., 105, 4895-4901, 440 https://doi.org/https://doi.org/10.1029/1999JD900303, 2000.

Chubarova, N. E., Pastukhova, A. S., Zhdanova, E. Y., Volpert, E. V, Smyshlyaev, S. P., and Galin, V. Y.: Effects of Ozone and Clouds on Temporal Variability of Surface UV Radiation and UV Resources over Northern Eurasia Derived from Measurements and Modeling, https://doi.org/10.3390/atmos11010059, 2020.

Dameris, M., Loyola, D. G., Nützel, M., Coldewey-Egbers, M., Lerot, C., Romahn, F., and van Roozendael, M.: Record low 445 ozone values over the Arctic in boreal spring 2020, 21, 617-633, https://doi.org/10.5194/acp-21-617-2021, 2021.

Diémoz, H., Siani, A. M., Casale, G. R., di Sarra, A., Serpillo, B., Petkov, B., Scaglione, S., Bonino, A., Facta, S., Fedele, F., Grifoni, D., Verdi, L., and Zipoli, G.: First national intercomparison of solar ultraviolet radiometers in Italy, 4, 1689-1703, https://doi.org/10.5194/amt-4-1689-2011, 2011.

di Sarra, A., Cacciani, M., Chamard, P., Cornwall, C., DeLuisi, J. J., Di Iorio, T., Disterhoft, P., Fiocco, G., Fuá, D., and 
Monteleone, F.: Effects of desert dust and ozone on the ultraviolet irradiance at the Mediterranean island of Lampedusa during PAUR II, J. Geophys. Res. Atmos., 107, PAU 2-1-PAU 2-14, https://doi.org/https://doi.org/10.1029/2000JD000139, 2002. di Sarra, A., Fua, D., Cacciani, M., Di Iorio, T., Disterhoft, P., Meloni, D., Monteleone, F., Piacentino, S., and Sferlazzo, D.: Determination of ultraviolet cosine-corrected irradiances and aerosol optical thickness by combined measurements with a Brewer spectrophotometer and a multifilter rotating shadowband radiometer, Appl. Opt., 47, 6142-6150, https://doi.org/10.1364/AO.47.006142, 2008.

Dobson, G. M. B., Brewer, A. W., and Cwilong, B. M.: Meteorology of the lower stratosphere, Proc. R. Soc. London, Ser. A, 185, 144-175, 1946.Eleftheratos, K., Kazadzis, S., Zerefos, C. S., Tourpali, K., Meleti, C., Balis, D., Zyrichidou, I., Lakkala, K., Feister, U., Koskela, T., Heikkilä, A., and Karhu, J. M.: Ozone and Spectroradiometric UV Changes in the Past 20 Years over High Latitudes, 53, 117-125, https://doi.org/10.1080/07055900.2014.919897, 2015.

460 Eleftheratos, K., Kapsomenakis, J., Zerefos, C. S., Bais, A. F., Fountoulakis, I., Dameris, M., Jöckel, P., Haslerud, A. S., Godin-Beekmann, S., Steinbrecht, W., Petropavlovskikh, I., Brogniez, C., Leblanc, T., Liley, J. B., Querel, R., and Swart, D. P. J.: Possible Effects of Greenhouse Gases to Ozone Profiles and DNA Active UV-B Irradiance at Ground Level, https://doi.org/10.3390/atmos11030228, 2020.

Fioletov, V. E., Kerr, J. B., McElroy, C. T., Wardle, D. I., Savastiouk, V., and Grajnar, T. S.: The Brewer reference triad, 465 Geophys. Res. Lett., 32, https://doi.org/https://doi.org/10.1029/2005GL024244, 2005.

Fitzka, M., Simic, S., and Hadzimustafic, J.: Trends in spectral UV radiation from long-term measurements at Hoher Sonnblick, Austria, Theor. Appl. Climatol., 110, 585-593, https://doi.org/10.1007/s00704-012-0684-0, 2012.

Fountoulakis, I., Bais, A. F., Fragkos, K., Meleti, C., Tourpali, K., and Zempila, M. M.: Short- and long-term variability of spectral solar UV irradiance at Thessaloniki, Greece: effects of changes in aerosols, total ozone and clouds, 16, 2493-2505, 470 https://doi.org/10.5194/acp-16-2493-2016, 2016.

Fountoulakis, I., Zerefos, C. S., Bais, A. F., Kapsomenakis, J., Koukouli, M.-E., Ohkawara, N., Fioletov, V., De Backer, H., Lakkala, K., Karppinen, T., and Webb, A. R.: Twenty-five years of spectral UV-B measurements over Canada, Europe and Japan: Trends and effects from changes in ozone, aerosols, clouds, and surface reflectivity, Comptes Rendus Geosci., 350, 393-402, https://doi.org/https://doi.org/10.1016/j.crte.2018.07.011, 2018.

475 Fountoulakis, I., Diémoz, H., Siani, A. M., Hülsen, G., and Gröbner, J.: Monitoring of solar spectral ultraviolet irradiance in Aosta, Italy, Earth Syst. Sci. Data, 12, 2787-2810, https://doi.org/10.5194/essd-12-2787-2020, 2020a.

Fountoulakis, I., Diémoz, H., Siani, A.-M., Laschewski, G., Filippa, G., Arola, A., Bais, A. F., De Backer, H., Lakkala, K., Webb, A. R., De Bock, V., Karppinen, T., Garane, K., Kapsomenakis, J., Koukouli, M.-E., and Zerefos, C. S.: Solar UV Irradiance in a Changing Climate: Trends in Europe and the Significance of Spectral Monitoring in Italy, 480 https://doi.org/10.3390/environments7010001, 2020b.

Fragkos, K., Bais, A. F., Fountoulakis, I., Balis, D., Tourpali, K., Meleti, C., and Zanis, P.: Extreme total column ozone events and effects on UV solar radiation at Thessaloniki, Greece, Theor. Appl. Climatol., 126, 505-517, https://doi.org/10.1007/s00704-015-1562-3, 2016. 
Garane, K., Bais, A. F., Kazadzis, S., Kazantzidis, A., and Meleti, C.: Monitoring of UV spectral irradiance at Thessaloniki 3215-2006, 2006.

GMAO: No Title, Glob. Model. Assim. Off. (GMAO), MERRA-2 tavgM_2d_slv_Nx 2d,Monthly mean,TimeAveraged,Single-Level,Assimilation,Single-Level Diagnostics V5.12.4, Greenbelt, MD, USA, Goddard Earth Sci. Data Inf. Serv. Cent. (GES DISC), https://doi.org/10.5067/AP1B0BA5PD2K, 2015a.

GMAO: No Title, Glob. Model. Assim. Off. (GMAO), MERRA-2 instM_3d_ana_Np 3d,Monthly mean,Instantaneous,Pressure-Level,Analysis,Analyzed Meteorol. Fields V5.12.4, Greenbelt, MD, USA, Goddard Earth Sci. Data Inf. Serv. Cent. (GES DIS, https://doi.org/10.5067/V92O8XZ30XBI, 2015b.

Griggs, M.: Absorption Coefficients of Ozone in the Ultraviolet and Visible Regions, J. Chem. Phys., 49, 857-859, https://doi.org/10.1063/1.1670152, 1968.

495 Gröbner, J. and Sperfeld, P.: Direct traceability of the portable QASUME irradiance scale to the primary irradiance standard of the PTB, 42, 134-139, https://doi.org/10.1088/0026-1394/42/2/008, 2005.

Häder, D.-P., Kumar, H. D., Smith, R. C., and Worrest, R. C.: Effects on aquatic ecosystems, J. Photochem. Photobiol. B Biol., 46, 53-68, https://doi.org/https://doi.org/10.1016/S1011-1344(98)00185-7, 1998.

Hoinka, K.P., Claude H., and Köhler, U.: On the correlation between tropopause pressure and ozone above Central Europe, 500 Geophys. Res. Lett., 23, 1753-1756, 1996.

Hooke, R. J., Higlett, M. P., Hunter, N., and O’Hagan, J. B.: Long term variations in erythema effective solar UV at Chilton, UK, from 1991 to 2015, Photochem. Photobiol. Sci., 16, 1596-1603, https://doi.org/10.1039/C7PP00053G, 2017.

Hülsen, G., Gröbner, J., Nevas, S., Sperfeld, P., Egli, L., Porrovecchio, G., and Smid, M.: Traceability of solar UV measurements using the Qasume reference spectroradiometer., Appl. Opt., 55, 7265-7275, 505 https://doi.org/10.1364/AO.55.007265, 2016.

Ialongo, I., Buchard, V., Brogniez, C., Casale, G. R., and Siani, A. M.: Aerosol Single Scattering Albedo retrieval in the UV range: an application to OMI satellite validation, 10, 331-340, https://doi.org/10.5194/acp-10-331-2010, 2010.

Di Ianni, A., Costabile, F., Barnaba, F., Di Liberto, L., Weinhold, K., Wiedensohler, A., Struckmeier, C., Drewnick, F., and Gobbi, G. P.: Black Carbon Aerosol in Rome (Italy): Inference of a Long-Term (2001-2017) Record and Related Trends from 510 AERONET Sun-Photometry Data, https://doi.org/10.3390/atmos9030081, 2018.

Inn, E. C. Y. and Tanaka, Y.: Absorption Coefficient of Ozone in the Ultraviolet and Visible Regions, J. Opt. Soc. Am., 43, 870-873, https://doi.org/10.1364/JOSA.43.000870, 1953.

IPCC: Climate Change 2013: The Physical Science Basis. Contribution of Working Group I to the Fifth Assessment Report of the Intergovernmental Panel on Climate Change [Stocker, T.F., D. Qin, G.-K. Plattner, M. Tignor, S.K. Allen, J. Boschung, 515 A. Nauels, Y. Xia, 2013.

Kazadzis, S., Kouremeti, N., Bais, A., Kazantzidis, A., and Meleti, C.: Aerosol forcing efficiency in the UVA region from spectral solar irradiance measurements at an urban environment, Ann. Geophys., 27, 2515-2522, 
https://doi.org/10.5194/angeo-27-2515-2009, 2009.

Kerr, J. B.: The Brewer Spectrophotometer BT - UV Radiation in Global Climate Change: Measurements, Modeling and 160-191, https://doi.org/10.1007/978-3-642-03313-1_6, 2010.

Kerr, J. B. and McElroy, C. T.: Evidence for Large Upward Trends of Ultraviolet-B Radiation Linked to Ozone Depletion, Science (80-. )., 262, 1032 LP - 1034, https://doi.org/10.1126/science.262.5136.1032, 1993.

Lakkala, K., Heikkilä, A., Kärhä, P., Ialongo, I., Karppinen, T., Karhu, J. M., Lindfors, A. V., and Meinander, O.: 25 years of spectral UV measurements at Sodankylä, AIP Conf. Proc., 1810, 110006, https://doi.org/10.1063/1.4975568, 2017.

Madronich, S., McKenzie, R. L., Björn, L. O., and Caldwell, M. M.: Changes in biologically active ultraviolet radiation reaching the Earth's surface, J. Photochem. Photobiol. B Biol., 46, 5-19, https://doi.org/https://doi.org/10.1016/S10111344(98)00182-1, 1998.

Manara, V., Beltrano, M. C., Brunetti, M., Maugeri, M., Sanchez-Lorenzo, A., Simolo, C., and Sorrenti, S.: Sunshine duration variability and trends in Italy from homogenized instrumental time series (1936-2013), J. Geophys. Res. Atmos., 120, 36223641, https://doi.org/https://doi.org/10.1002/2014JD022560, 2015.

Manara, V., Brunetti, M., Celozzi, A., Maugeri, M., Sanchez-Lorenzo, A., and Wild, M.: Detection of dimming/brightening in Italy from homogenized all-sky and clear-sky surface solar radiation records and underlying causes (1959-2013), 16, 1114511161, https://doi.org/10.5194/acp-16-11145-2016, 2016.

Manney, G. L., Santee, M. L., Rex, M., Livesey, N. J., Pitts, M. C., Veefkind, P., Nash, E. R., Wohltmann, I., Lehmann, R., Froidevaux, L., Poole, L. R., Schoeberl, M. R., Haffner, D. P., Davies, J., Dorokhov, V., Gernandt, H., Johnson, B., Kivi, R., Kyrö, E., Larsen, N., Levelt, P. F., Makshtas, A., McElroy, C. T., Nakajima, H., Parrondo, M. C., Tarasick, D. W., von der Gathen, P., Walker, K. A., and Zinoviev, N. S.: Unprecedented Arctic ozone loss in 2011, Nature, 478, 469-475, https://doi.org/10.1038/nature10556, 2011.

Masiol, M., Squizzato, S., Formenton, G., Harrison, R. M., and Agostinelli, C.: Air quality across a European hotspot: Spatial gradients, seasonality, diurnal cycles and trends in the Veneto region, NE Italy, Sci. Total Environ., 576, 210-224, https://doi.org/https://doi.org/10.1016/j.scitotenv.2016.10.042, 2017.

Mateos, D., di Sarra, A., Meloni, D., Di Biagio, C., and Sferlazzo, D. M.: Experimental determination of cloud influence on the spectral UV irradiance and implications for biological effects, J. Atmos. Solar-Terrestrial Phys., 73, 1739-1746, https://doi.org/https://doi.org/10.1016/j.jastp.2011.04.003, 2011.

Mateos, D., di Sarra, A., Bilbao, J., Meloni, D., Pace, G., de Miguel, A., and Casasanta, G.: Spectral attenuation of global and diffuse UV irradiance and actinic flux by clouds, Q. J. R. Meteorol. Soc., 141, 109-113, https://doi.org/https://doi.org/10.1002/qj.2341, 2015.

McConnell, J. C., Henderson, G. S., Barrie, L., Bottenheim, J., Niki, H., Langford, C. H., and Templeton, E. M. J.:

550 Photochemical bromine production implicated in Arctic boundary-layer ozone depletion, Nature, 355, 150-152, https://doi.org/10.1038/355150a0, 1992. 
McKenzie, R., Bernhard, G., Liley, B., Disterhoft, P., Rhodes, S., Bais, A., Morgenstern, O., Newman, P., Oman, L., Brogniez, C., and Simic, S.: Success of Montreal Protocol Demonstrated by Comparing High-Quality UV Measurements with "World Avoided" Calculations from Two Chemistry-Climate Models, Sci. Rep., 9, 12332, https://doi.org/10.1038/s41598-019-48625z, 2019.

Mckinlay, A. F. and Diffey, B. L.: A reference action spectrum for ultraviolet induced erythema in human skin., 6, 17-22, 1987.

Meloni, D., Casale, G. R., Siani, A. M., Palmieri, S., and Cappellani, F.: Solar UV Dose Patterns in Italy, Photochem. Photobiol., 71, 681-690, https://doi.org/https://doi.org/10.1562/0031-8655(2000)0710681SUDPII2.0.CO2, 2000.

Meloni, D., di Sarra, A., Monteleone, F., Pace, G., Piacentino, S., and Sferlazzo, D. M.: Seasonal transport patterns of intense Saharan dust events at the Mediterranean island of Lampedusa, Atmos. Res., 88, 134-148, https://doi.org/https://doi.org/10.1016/j.atmosres.2007.10.007, 2008.

Monge-Sanz, B., Casale, G. R., Palmieri, S., and Siani, A.: An investigation on total ozone over western Mediterranean, Nuovo Cim. C, 26, 2003.

565 Morgenstern, O., Braesicke, P., Hurwitz, M. M., O’Connor, F. M., Bushell, A. C., Johnson, C. E., and Pyle, J. A.: The World Avoided by the Montreal Protocol, Geophys. Res. Lett., 35, https://doi.org/https://doi.org/10.1029/2008GL034590, 2008.

Neu, J. L., Flury, T., Manney, G. L., Santee, M. L., Livesey, N. J., and Worden, J.: Tropospheric ozone variations governed by changes in stratospheric circulation, Nat. Geosci., 7, 340-344, https://doi.org/10.1038/ngeo2138, 2014.

Newman, P. A. and McKenzie, R.: UV impacts avoided by the Montreal Protocol, Photochem. Photobiol. Sci., 10, 1152-1160, https://doi.org/10.1039/C0PP00387E, 2011.

Orza, J. A. G. and Perrone, M. R.: Trends in the aerosol load properties over south eastern Italy, IOP Conf. Ser. Earth Environ. Sci., 28, 12011, https://doi.org/10.1088/1755-1315/28/1/012011, 2015.

Pandey, P., Gillotay, D., and Depiesse, C.: Climatology of Ultra Violet (UV) irradiance as measured through the Belgian ground-based monitoring network during the time period of 1995-2014, in: EGU General Assembly Conference Abstracts, EPSC2016-13080, 2016.

Paul, N. D. and Gwynn-Jones, D.: Ecological roles of solar UV radiation: towards an integrated approach, Trends Ecol. Evol., 18, 48-55, https://doi.org/https://doi.org/10.1016/S0169-5347(02)00014-9, 2003.

Petkov, B. H., Vitale, V., Tomasi, C., Siani, A. M., Seckmeyer, G., Webb, A. R., Smedley, A. R. D., Casale, G. R., Werner, R., Lanconelli, C., Mazzola, M., Lupi, A., Busetto, M., Diémoz, H., Goutail, F., Köhler, U., Mendeva, B. D., Josefsson, W., 580 Moore, D., Bartolomé, M. L., Moreta González, J. R., Mišaga, O., Dahlback, A., Tóth, Z., Varghese, S., De Backer, H., Stübi, R., and Vaníček, K.: Response of the ozone column over Europe to the 2011 Arctic ozone depletion event according to groundbased observations and assessment of the consequent variations in surface UV irradiance, Atmos. Environ., 85, 169-178, https://doi.org/https://doi.org/10.1016/j.atmosenv.2013.12.005, 2014.

Pfeifroth, U., Sanchez-Lorenzo, A., Manara, V., Trentmann, J., and Hollmann, R.: Trends and Variability of Surface Solar

Radiation in Europe Based On Surface- and Satellite-Based Data Records, J. Geophys. Res. Atmos., 123, 1735-1754, 
https://doi.org/https://doi.org/10.1002/2017JD027418, 2018.

Pommereau, J.-P., Goutail, F., Pazmino, A., Lefèvre, F., Chipperfield, M. P., Feng, W., Van Roozendael, M., Jepsen, N., Hansen, G., Kivi, R., Bognar, K., Strong, K., Walker, K., Kuzmichev, A., Khattatov, S., and Sitnikova, V.: Recent Arctic ozone depletion: Is there an impact of climate change?, Comptes Rendus Geosci., 350, 347-353, https://doi.org/https://doi.org/10.1016/j.crte.2018.07.009, 2018.

Putaud, J. P., Cavalli, F., Martins dos Santos, S., and Dell'Acqua, A.: Long-term trends in aerosol optical characteristics in the Po Valley, Italy, 14, 9129-9136, https://doi.org/10.5194/acp-14-9129-2014, 2014.

Raptis, I.-P., Eleftheratos, K., Kazadzis, S., Kosmopoulos, P., Papachristopoulou, K., and Solomos, S.: The Combined Effect of Ozone and Aerosols on Erythemal Irradiance in an Extremely Low Ozone Event during May 2020, 595 https://doi.org/10.3390/atmos12020145, 2021.

Redondas, A. and Rodriguez-Franco, J.: Eighth Intercomparison Campaign of the Regional Brewer Calibration Center for Europe (RBCC-E), GAW Report- No. 223, WMO - GAW report, Geneva, Switzeland, 2015.

Redondas, A., Carreño, V., León-Luis, S. F., Hernández-Cruz, B., López-Solano, J., Rodriguez-Franco, J. J., Vilaplana, J. M., Gröbner, J., Rimmer, J., Bais, A. F., Savastiouk, V., Moreta, J. R., Boulkelia, L., Jepsen, N., Wilson, K. M., Shirotov, V., and

600 Karppinen, T.: EUBREWNET RBCC-E Huelva 2015 Ozone Brewer Intercomparison, 18, 9441-9455, https://doi.org/10.5194/acp-18-9441-2018, 2018.

Reed, R.J.: The role of vertical motions in ozone-weather relatinships, J. Meteorol., 7, 263-267, 1950.

Rizza, U., Mancinelli, E., Morichetti, M., Passerini, G., and Virgili, S.: Aerosol Optical Depth of the Main Aerosol Species over Italian Cities Based on the NASA/MERRA-2 Model Reanalysis, https://doi.org/10.3390/atmos10110709, 2019.

605 Siani, A., Casale, G. R., and Galliani, A.: Investigation on a low ozone episode at the end of November 2000 and its effect on ultraviolet radiation, Opt. Eng., 41, 3082-3089, https://doi.org/10.1117/1.1516821, 2002.

Siani, A. M., Frasca, F., Scarlatti, F., Religi, A., Diémoz, H., Casale, G. R., Pedone, M., and Savastiouk, V.: Examination on total ozone column retrievals by Brewer spectrophotometry using different processing software, 11, 5105-5123, https://doi.org/10.5194/amt-11-5105-2018, 2018.

610 Sofieva, V. F., Kyrölä, E., Laine, M., Tamminen, J., Degenstein, D., Bourassa, A., Roth, C., Zawada, D., Weber, M., Rozanov, A., Rahpoe, N., Stiller, G., Laeng, A., von Clarmann, T., Walker, K. A., Sheese, P., Hubert, D., van Roozendael, M., Zehner, C., Damadeo, R., Zawodny, J., Kramarova, N., and Bhartia, P. K.: Merged SAGE II, Ozone_cci and OMPS ozone profile dataset and evaluation of ozone trends in the stratosphere, 17, 12533-12552, https://doi.org/10.5194/acp-17-12533-2017, 2017.

615 Solomon, S., Garcia, R. R., Rowland, F. S., and Wuebbles, D. J.: On the depletion of Antarctic ozone, Nature, 321, 755-758, https://doi.org/10.1038/321755a0, 1986.

Solomon, S., Ivy, D. J., Kinnison, D., Mills, M. J., Neely, R. R., and Schmidt, A.: Emergence of healing in the Antarctic ozone layer, Science (80-. )., 353, 269 LP - 274, https://doi.org/10.1126/science.aae0061, 2016.

Staehelin, J., Harris, N. R. P., Appenzeller, C., and Eberhard, J.: Ozone trends: A review, Rev. Geophys., 39, 231-290, 
https://doi.org/https://doi.org/10.1029/1999RG000059, 2001.

Steinbrecht, W., Claude, H., Köhler, U., and Hoinka, K. P.: Correlations between tropopause height and total ozone: Implications for long-term changes, J. Geophys. Res. Atmos., 103, 19183-19192, https://doi.org/https://doi.org/10.1029/98JD01929, 1998.

Steinbrecht, W., Froidevaux, L., Fuller, R., Wang, R., Anderson, J., Roth, C., Bourassa, A., Degenstein, D., Damadeo, R., Zawodny, J., Frith, S., McPeters, R., Bhartia, P., Wild, J., Long, C., Davis, S., Rosenlof, K., Sofieva, V., Walker, K., Rahpoe, N., Rozanov, A., Weber, M., Laeng, A., von Clarmann, T., Stiller, G., Kramarova, N., Godin-Beekmann, S., Leblanc, T., Querel, R., Swart, D., Boyd, I., Hocke, K., Kämpfer, N., Maillard Barras, E., Moreira, L., Nedoluha, G., Vigouroux, C., Blumenstock, T., Schneider, M., García, O., Jones, N., Mahieu, E., Smale, D., Kotkamp, M., Robinson, J., Petropavlovskikh, I., Harris, N., Hassler, B., Hubert, D., and Tummon, F.: An update on ozone profile trends for the period 2000 to 2016, 17, 10675-10690, https://doi.org/10.5194/acp-17-10675-2017, 2017.

Svendby, T., Hansen, G. H., Bäcklund, A., and Dahlback, A.: No Title, Oslo, Norway, 39 pp., 2018.

Szeląg, M. E., Sofieva, V. F., Degenstein, D., Roth, C., Davis, S., and Froidevaux, L.: Seasonal stratospheric ozone trends over 2000-2018 derived from several merged data sets, 20, 7035-7047, https://doi.org/10.5194/acp-20-7035-2020, 2020.

Vanicek, K.: Differences between ground Dobson, Brewer and satellite TOMS-8, GOME-WFDOAS total ozone observations at Hradec kralove, Czech, Atmos. Chem. Phys., 6, https://doi.org/10.5194/acpd-6-5839-2006, 2006.

Varotsos, C., Cartalis, C., Vlamakis, A., Tzanis, C., and Keramitsoglou, I.: The long-term coupling between column ozone and tropopause properties, J. Clim., 17, 3843-3854, 2004.

Varotsos, C. A., Cracknell, A. P., and Tzanis, C.: The exceptional ozone depletion over the Arctic in January-March 2011, Remote Sens. Lett., 3, 343-352, https://doi.org/10.1080/01431161.2011.597792, 2012.

640 Vaughan, G. and Price, J. D.: On the relation between total ozone and meteorology, Q. J. R. Meteorol. Soc., 117, 1281-1298, https://doi.org/https://doi.org/10.1002/qj.49711750208, 1991.

Wargan, K., Orbe, C., Pawson, S., Ziemke, J. R., Oman, L. D., Olsen, M. A., Coy, L., and Emma Knowland, K.: Recent Decline in Extratropical Lower Stratospheric Ozone Attributed to Circulation Changes, Geophys. Res. Lett., 45, 5166-5176, https://doi.org/https://doi.org/10.1029/2018GL077406, 2018.

645 Weber, M., Dikty, S., Burrows, J. P., Garny, H., Dameris, M., Kubin, A., Abalichin, J., and Langematz, U.: The BrewerDobson circulation and total ozone from seasonal to decadal time scales, 11, 11221-11235, https://doi.org/10.5194/acp-1111221-2011, 2011.

Weber, M., Coldewey-Egbers, M., Fioletov, V. E., Frith, S. M., Wild, J. D., Burrows, J. P., Long, C. S., and Loyola, D.: Total ozone trends from 1979 to 2016 derived from five merged observational datasets - the emergence into ozone recovery, 18, 2097-2117, https://doi.org/10.5194/acp-18-2097-2018, 2018.

Williamson, C. E., Neale, P. J., Hylander, S., Rose, K. C., Figueroa, F. L., Robinson, S. A., Häder, D.-P., Wängberg, S.-Å., and Worrest, R. C.: The interactive effects of stratospheric ozone depletion, UV radiation, and climate change on aquatic ecosystems, Photochem. Photobiol. Sci., 18, 717-746, https://doi.org/10.1039/C8PP90062K, 2019. 
Wohltmann, I., von der Gathen, P., Lehmann, R., Maturilli, M., Deckelmann, H., Manney, G. L., Davies, J., Tarasick, D., 655 Jepsen, N., Kivi, R., Lyall, N., and Rex, M.: Near-Complete Local Reduction of Arctic Stratospheric Ozone by Severe Chemical Loss in Spring 2020, Geophys. Res. Lett., 47, e2020GL089547, https://doi.org/https://doi.org/10.1029/2020GL089547, 2020.

Zerefos, C. S., Bais, A. F., Meleti, C., and Ziomas, I. C.: A note on the recent increase of Solar UV-B radiation over northern middle latitudes, Geophys. Res. Lett., 22, 1245-1247, https://doi.org/https://doi.org/10.1029/95GL01187, 1995.

660 Zhang, H., Wang, J., Castro García, L., Zeng, J., Dennhardt, C., Liu, Y., and Krotkov, N. A.: Surface erythemal UV irradiance in the continental United States derived from ground-based and OMI observations: quality assessment, trend analysis and sampling issues, 19, 2165-2181, https://doi.org/10.5194/acp-19-2165-2019, 2019.

Zhao, X., Fioletov, V., Brohart, M., Savastiouk, V., Abboud, I., Ogyu, A., Davies, J., Sit, R., Lee, S. C., Cede, A., Tiefengraber, M., Müller, M., Griffin, D., and McLinden, C.: The world Brewer reference triad - updated performance assessment and new 665 double triad, 2020, 1-34, https://doi.org/10.5194/amt-2020-324, 2020.

Zhao, X., Fioletov, V., Brohart, M., Savastiouk, V., Abboud, I., Ogyu, A., Davies, J., Sit, R., Lee, S. C., Cede, A., Tiefengraber, M., Müller, M., Griffin, D., and McLinden, C.: The world Brewer reference triad - updated performance assessment and new double triad, 14, 2261-2283, https://doi.org/10.5194/amt-14-2261-2021, 2021. 


\section{Figures}

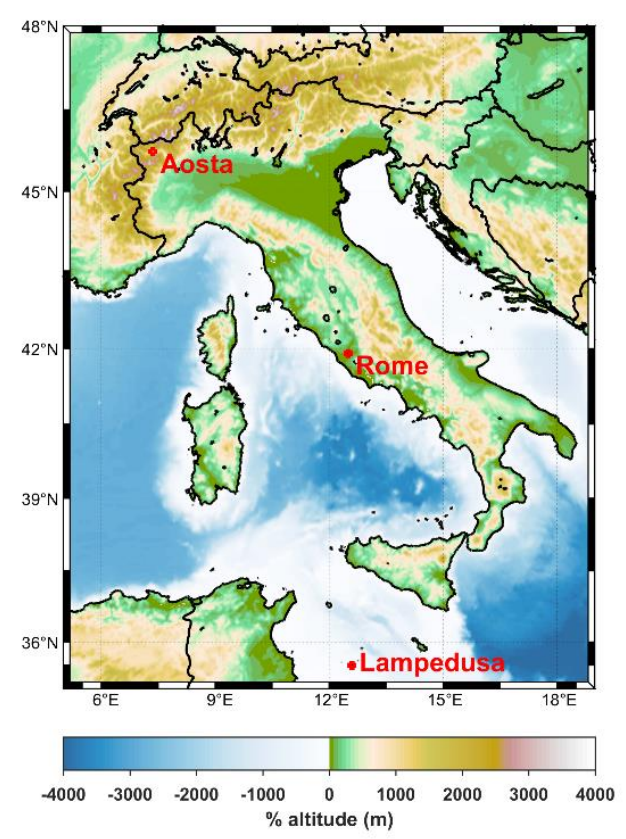

Figure 1: Topographic map of Italy and the three sites for which measurements are analysed in the study. 

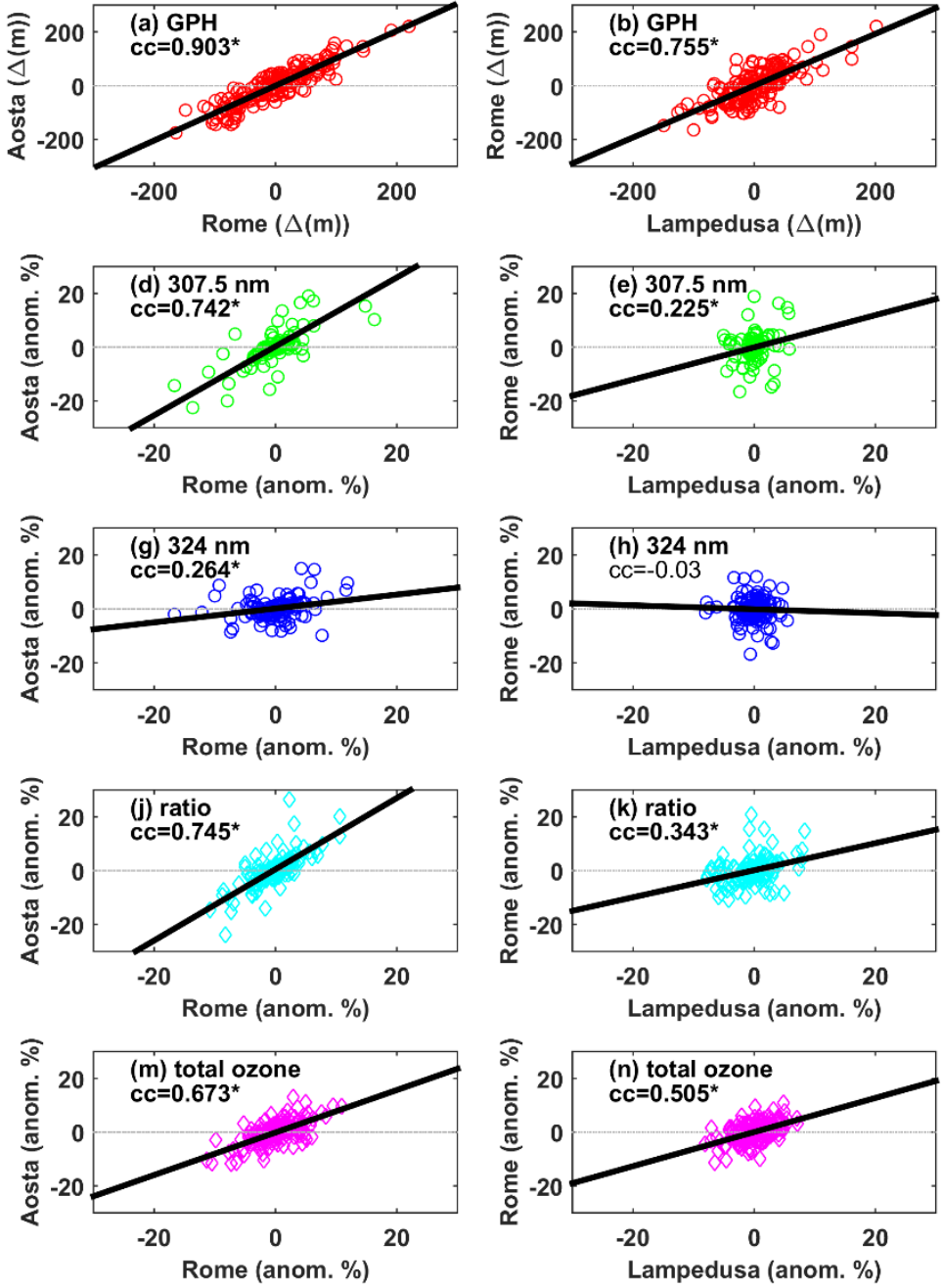
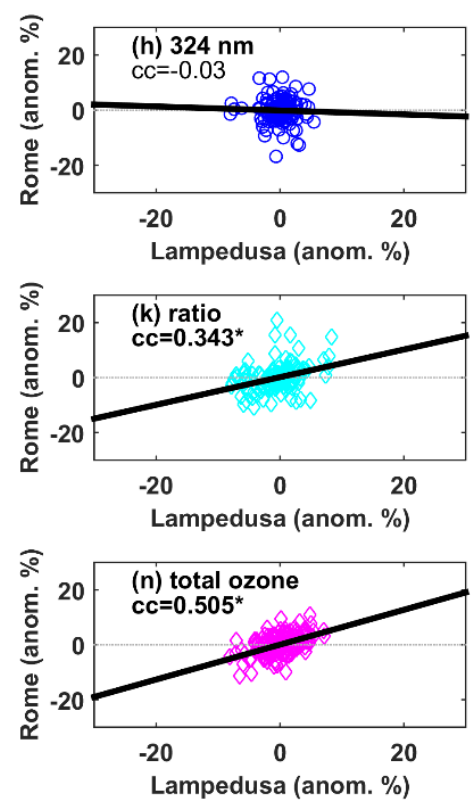
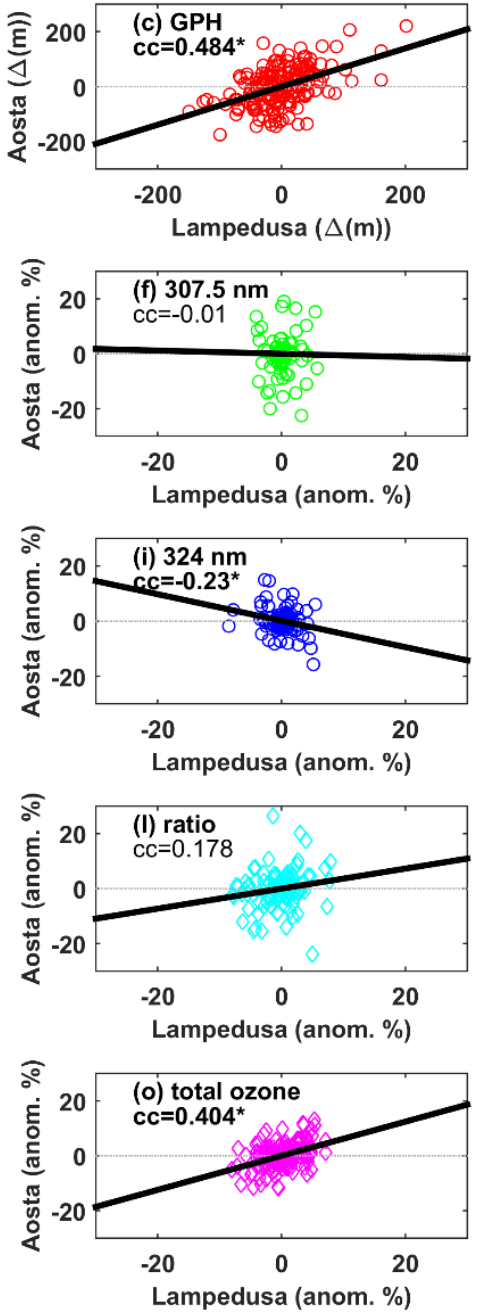

Figure 2: Scatter plots and correlation coefficients (cc) between the monthly anomalies of GPH (first row), irra-diance at 307.5 nm (second row), irradiance $324 \mathrm{~nm}$ (third row), $307.5 / 324 \mathrm{~nm}$ ratio (fourth row), and total ozone (fifth row) in terms of anomalies for the pairs Rome - Aosta (first column), Lampedusa - Rome (second column), and Lampedusa - Aosta (third column). Numbers in bold with asterisk denote statistical significance. 
https://doi.org/10.5194/acp-2021-616

Preprint. Discussion started: 2 September 2021

(c) Author(s) 2021. CC BY 4.0 License.

(c) (i)
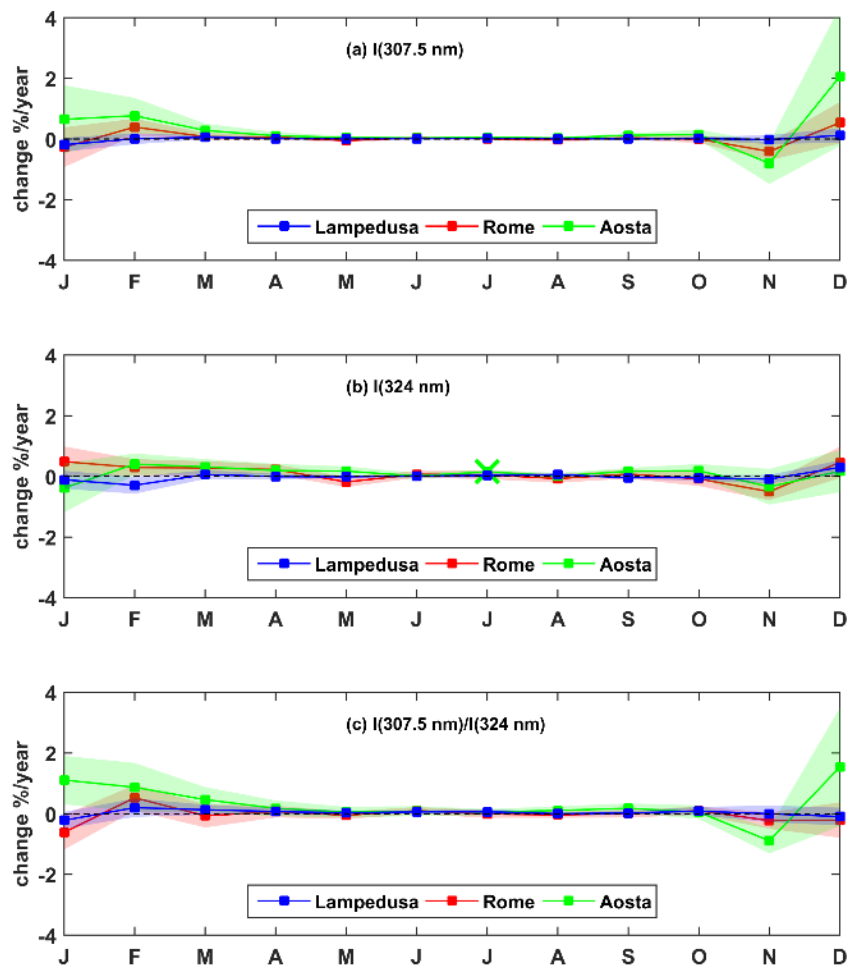

680

Figure 3: Average change (\%) per year of (a) irradiance at $307.5 \mathrm{~nm}$, (b) irradiance at $324 \mathrm{~nm}$, and (c) the $307.5 / 324 \mathrm{~nm}$ ratio. Results are for $\mathrm{SZA}=67^{\circ}$ for the period September 2006 - August 2020. Statistically significant changes have been marked with $\mathrm{x}$. Shaded areas correspond to the 1-sigma standard deviation. 
https://doi.org/10.5194/acp-2021-616

Preprint. Discussion started: 2 September 2021

(c) Author(s) 2021. CC BY 4.0 License.

(c) (i)
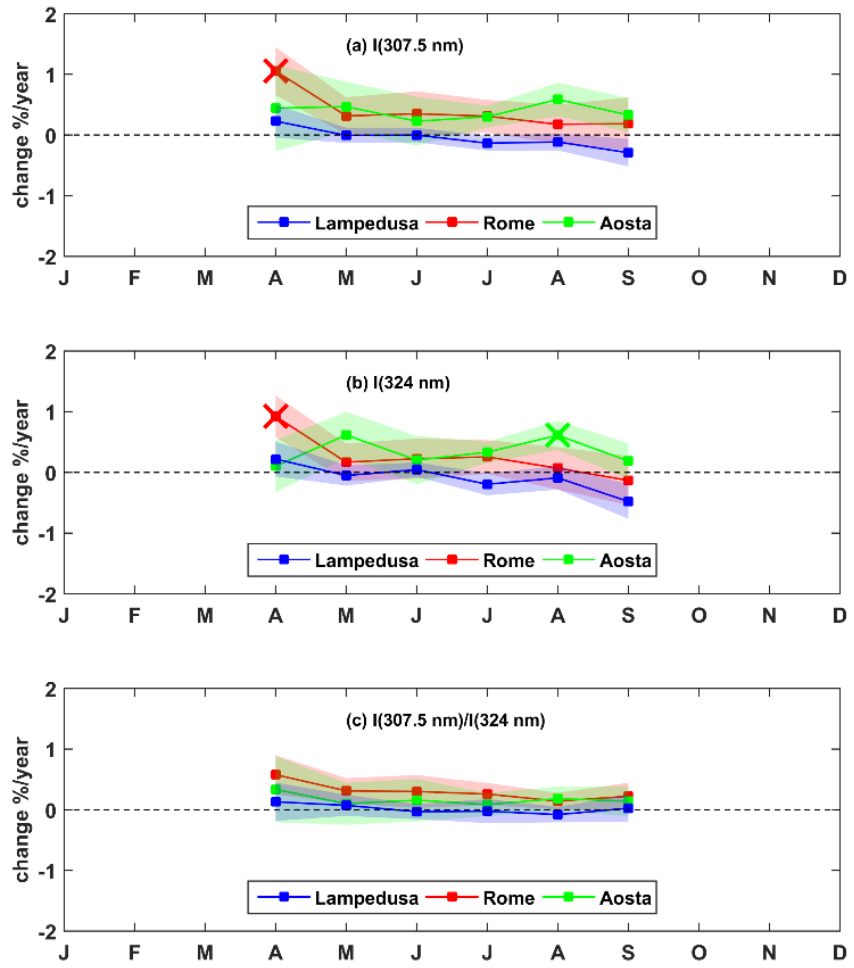

685 Figure 4: Average (\%) change per year of (a) irradiance at $307.5 \mathrm{~nm}$, (b) irradiance at $324 \mathrm{~nm}$, (c) the ratio between the irradiances at $307.5 \mathrm{~nm}$ and $324 \mathrm{~nm}$. Results are for $45^{\circ}$ the period $2006-2020$. Statistically significant changes have been marked with $x$. Shaded areas correspond to the 1-sigma standard deviation. 
https://doi.org/10.5194/acp-2021-616

Preprint. Discussion started: 2 September 2021

(C) Author(s) 2021. CC BY 4.0 License.

(c) (i)

Atmospheric

Chemistry

and Physics

Discussions
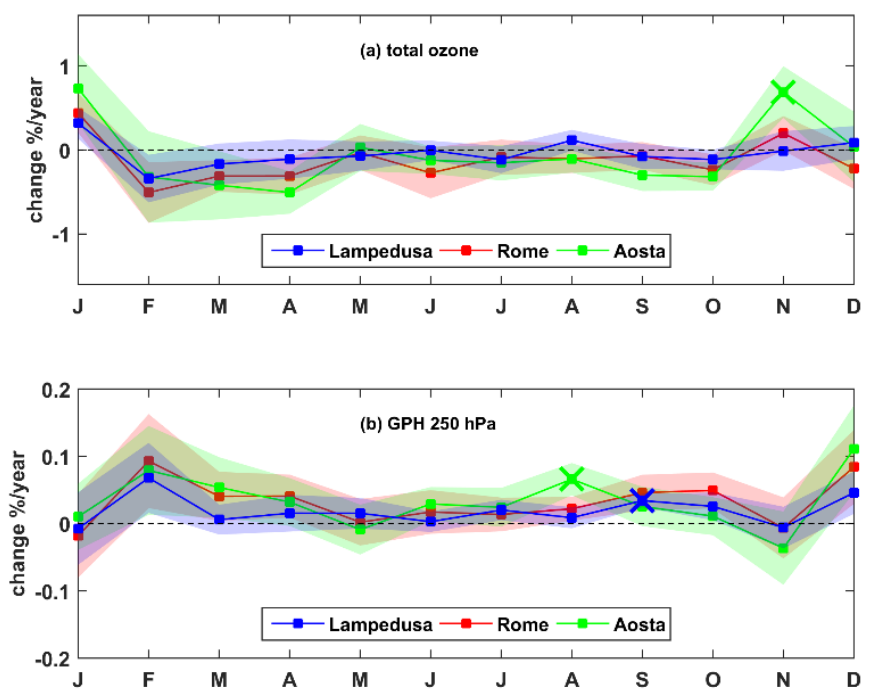

Figure 5: Average (\%) change per year of (a) total ozone, and (b) GPH for the period 2006 - 2020. Statistically significant changes have been marked with $x$. 

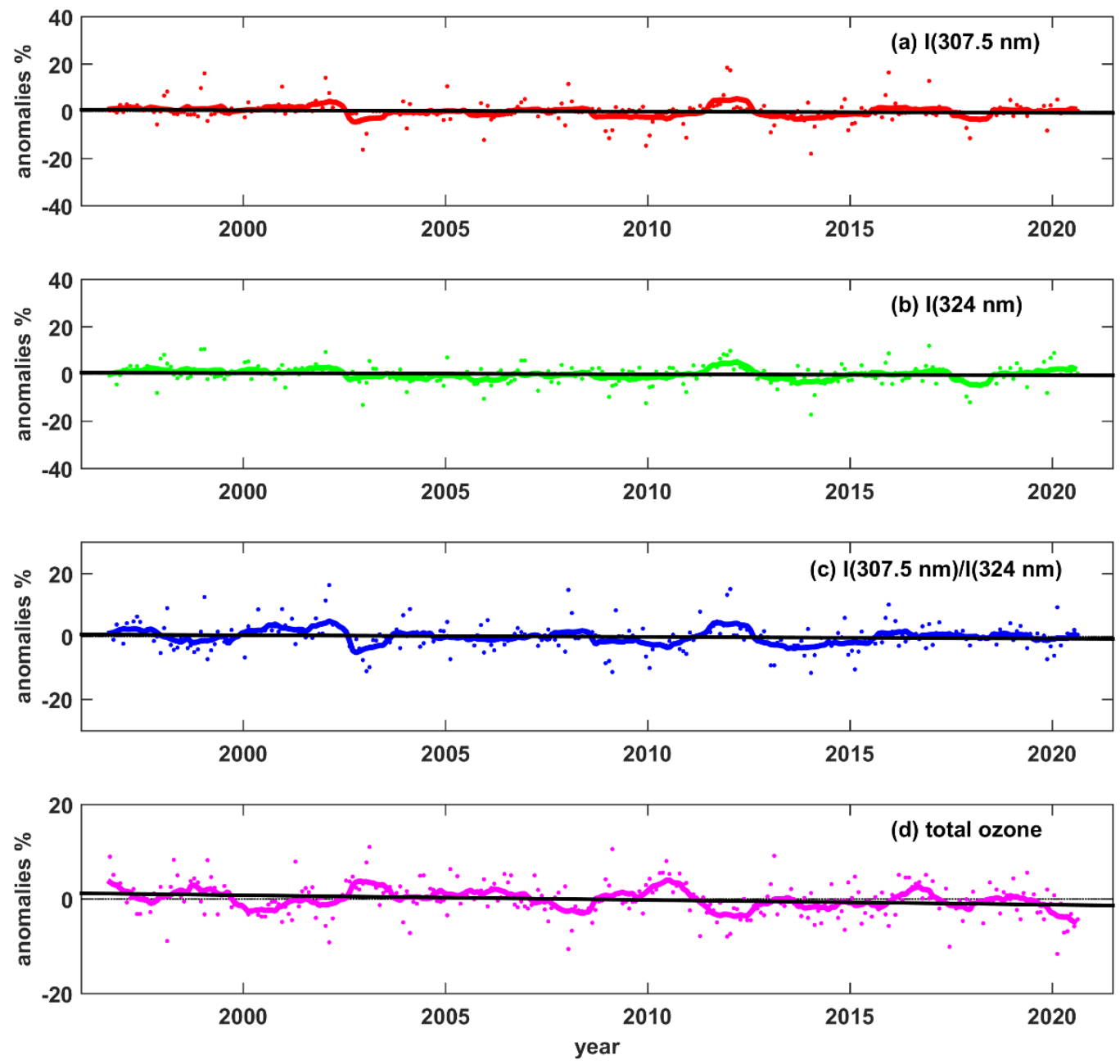

Figure 6. Anomalies (\% differences relative to the monthly climatological values, represented by dots), 12-month moving averages (thick coloured lines), and trends (black lines) for Rome, for the monthly averages of (a) the irradiance at $307.5 \mathrm{~nm}$, (b) the irradiance at $324 \mathrm{~nm}$, (c) the ratio between the $307.5 \mathrm{~nm}$ and $324 \mathrm{~nm}$ irradiances, and (d) the total ozone. 
https://doi.org/10.5194/acp-2021-616

Preprint. Discussion started: 2 September 2021

(c) Author(s) 2021. CC BY 4.0 License.

(c) (i)
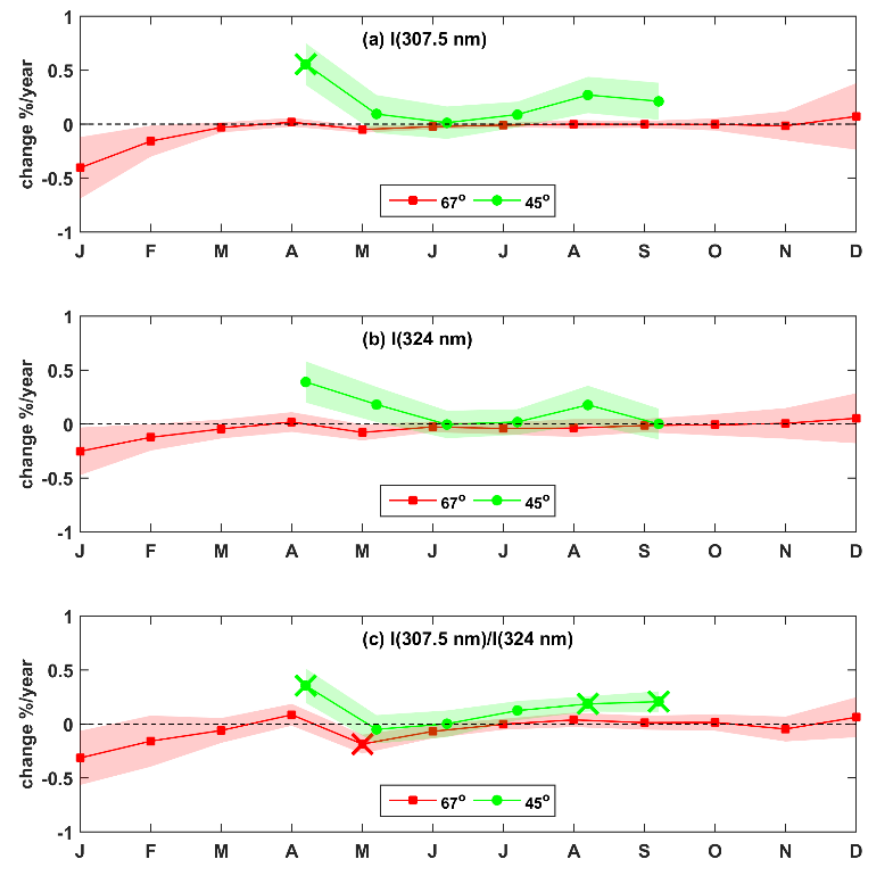

Figure 7: Average (\%) change per year of (a) irradiance at $307.5 \mathrm{~nm}$, (b) irradiance at $324 \mathrm{~nm}$, (c) the ratio between the irradiances at $307.5 \mathrm{~nm}$ and $324 \mathrm{~nm}$, for Rome. Trends of the irradiances and the ratio are presented for the $45^{\circ}$ and $67.5^{\circ} \mathrm{SZAs} . \mathrm{Statistically}^{\circ}$ significant trends have been marked with $x$. Shaded areas correspond to the 1-sigma standard deviation.
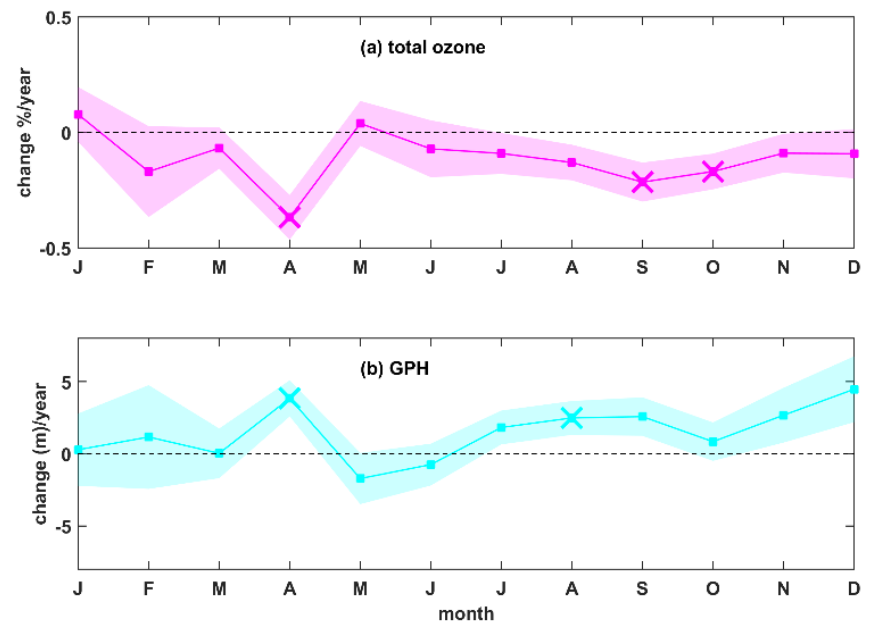

Figure 8: Average (\%) change per year of (a) total ozone, and (b) GPH, for Rome. Statistically significant trends have been marked with $\mathrm{x}$. Shaded areas correspond to the 1-sigma standard deviation. 
https://doi.org/10.5194/acp-2021-616

Preprint. Discussion started: 2 September 2021

(c) Author(s) 2021. CC BY 4.0 License.

\section{Atmospheric \\ Chemistry \\ and Physics \\ Discussions}
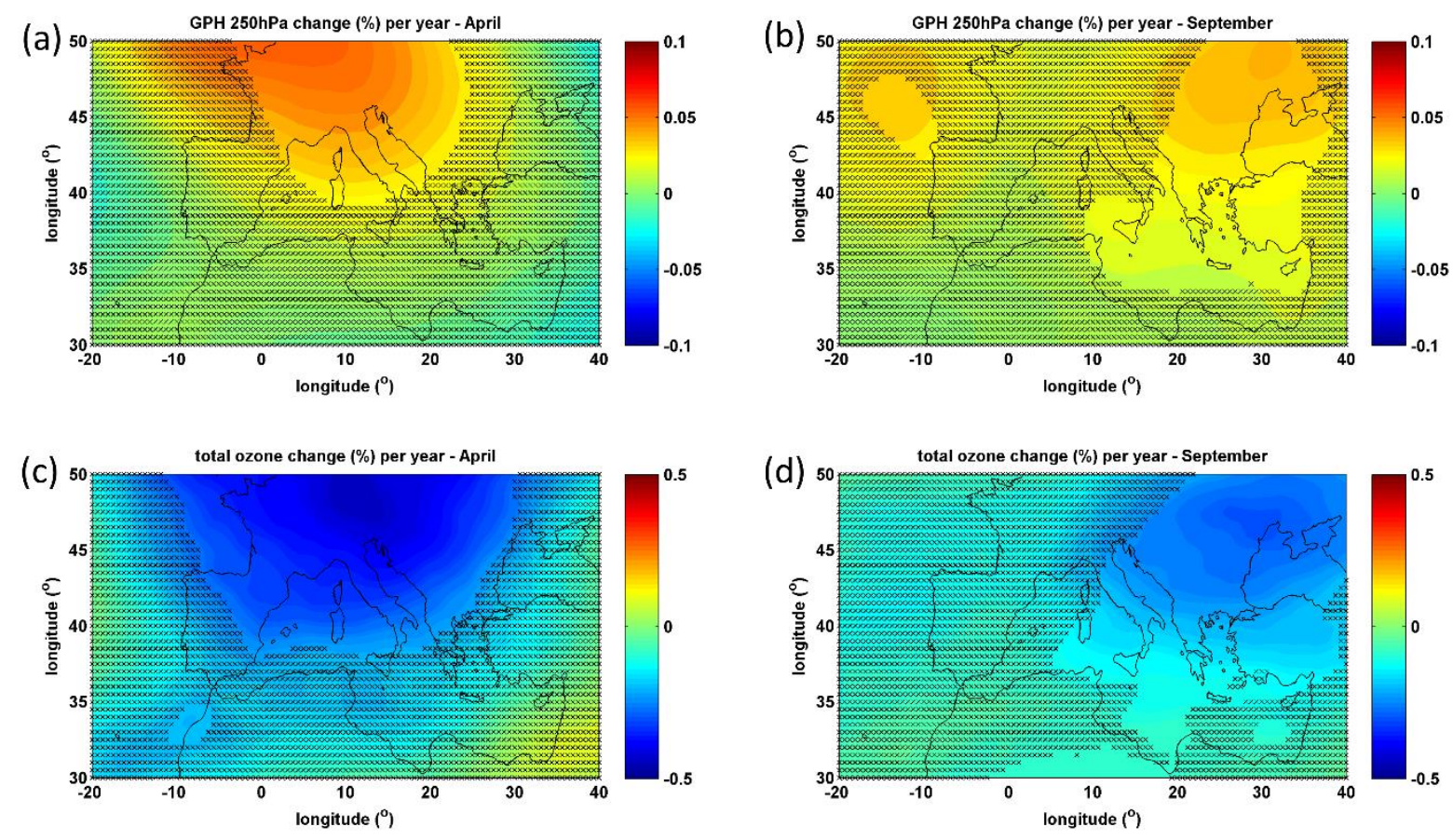

Figure 9: Changes (\%) of GPH at 250 hPa (a,b) and total ozone (c,d) and for April (a,c), and September (b,d). Areas over which changes are not statistically significant are covered by $x$. 
Tables

Table 1: Correlation coefficients between the anomalies of GPH and other parameters (total ozone, irradiance at 307.5 and $324 \mathrm{~nm}$ and $307.5 / 324 \mathrm{~nm}$ ratio) for four different seasons of the year. Values in bold de-note statistically significant correlation or anticorrelation.

\begin{tabular}{|c|c|c|c|c|}
\hline & Lampedusa & Rome (2006-2020) & Rome (1996-2020) & Aosta \\
\hline & \multicolumn{4}{|c|}{ Total ozone } \\
\hline Winter & -0.69 & -0.69 & -0.74 & -0.63 \\
\hline Spring & -0.64 & -0.46 & -0.56 & -0.68 \\
\hline Summer & -0.54 & -0.56 & -0.49 & -0.30 \\
\hline \multirow[t]{2}{*}{ Autumn } & -0.51 & -0.62 & -0.70 & -0.70 \\
\hline & \multicolumn{4}{|c|}{$307.5 \mathrm{~nm}$ irradiance $\left(45^{\circ}\right)$} \\
\hline Winter & - & - & - & - \\
\hline Spring & 0.51 & 0.59 & 0.57 & 0.60 \\
\hline Summer & 0.41 & 0.55 & 0.46 & 0.44 \\
\hline \multirow[t]{2}{*}{ Autumn } & 0.49 & 0.33 & 0.58 & 0.26 \\
\hline & \multicolumn{4}{|c|}{$307.5 \mathrm{~nm}$ irradiance $\left(67^{\circ}\right)$} \\
\hline Winter & 0.55 & 0.52 & 0.53 & 0.55 \\
\hline Spring & 0.51 & 0.40 & 0.47 & 0.58 \\
\hline Summer & 0.58 & 0.49 & 0.19 & 0.38 \\
\hline \multirow[t]{2}{*}{ Autumn } & 0.52 & 0.64 & 0.48 & 0.64 \\
\hline & \multicolumn{4}{|c|}{$324 \mathrm{~nm}$ irradiance $\left(45^{\circ}\right)$} \\
\hline Winter & - & - & - & - \\
\hline Spring & 0.09 & 0.49 & 0.42 & 0.36 \\
\hline Summer & -0.03 & 0.48 & 0.42 & 0.24 \\
\hline \multirow[t]{2}{*}{ Autumn } & 0.12 & 0.14 & 0.34 & -0.42 \\
\hline & \multicolumn{4}{|c|}{$324 \mathrm{~nm}$ irradiance $\left(67^{\circ}\right)$} \\
\hline Winter & 0.50 & 0.44 & 0.38 & 0.10 \\
\hline Spring & 0.08 & 0.44 & 0.40 & 0.31 \\
\hline Summer & 0.10 & 0.42 & 0.20 & -0.02 \\
\hline
\end{tabular}




\begin{tabular}{|c|c|c|c|c|}
\hline Autumn & 0.07 & 0.42 & 0.33 & 0.41 \\
\hline & \multicolumn{4}{|c|}{$307.5 / 324 \mathrm{~nm}$ ratio $\left(45^{\circ}\right)$} \\
\hline Winter & - & - & - & - \\
\hline Spring & 0.65 & - & 0.52 & 0.69 \\
\hline Summer & 0.61 & 0.52 & 0.39 & 0.54 \\
\hline \multirow[t]{2}{*}{ Autumn } & 0.62 & 0.24 & $\mathbf{0 . 5 3}$ & 0.76 \\
\hline & \multicolumn{4}{|c|}{$307.5 / 324 \mathrm{~nm}$ ratio $\left(67^{\circ}\right)$} \\
\hline Winter & 0.54 & 0.44 & 0.62 & 0.67 \\
\hline Spring & 0.44 & 0.19 & 0.39 & 0.66 \\
\hline Summer & 0.59 & 0.50 & 0.17 & 0.55 \\
\hline Autumn & 0.54 & 0.69 & 0.51 & 0.83 \\
\hline
\end{tabular}

Table 2: Trends and statistics for the $307.5 \mathrm{~nm}$ irradiance, the $324 \mathrm{~nm}$ irradiance, the $307.5 / 324 \mathrm{~nm}$ ratio, and the total ozone for

Rome in 1996 - 2020. Significance level is set at 0.05 . Statistically significant trends are in bold.

\begin{tabular}{|c|c|c|c|c|}
\hline & Change \%/year & Standard deviation & T-statistic & p-value \\
\hline $307.5 \mathrm{~nm}$ & -0.04 & 0.04 & -1.30 & 0.20 \\
\hline $324 \mathrm{~nm}$ & -0.04 & 0.04 & -1.30 & 0.20 \\
\hline $307.5 / 324 \mathrm{~nm}$ & -0.06 & 0.04 & -1.42 & 0.16 \\
\hline TOC & $\mathbf{- 0 . 1 0}$ & 0.03 & -3.21 & $<0.01$ \\
\hline
\end{tabular}

